Research, part of a Special Feature on Adaptation in Fire-Prone Landscapes: Interactions of Policies, Management. Wildfire, and Social Networks in Oregon, USA

\title{
Effects of accelerated wildfire on future fire regimes and implications for the United States federal fire policy
}

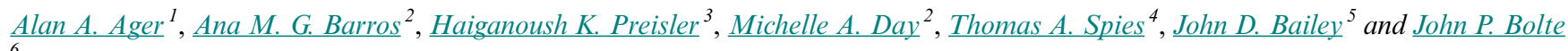

\begin{abstract}
Wildland fire suppression practices in the western United States are being widely scrutinized by policymakers and scientists as costs escalate and large fires increasingly affect social and ecological values. One potential solution is to change current fire suppression tactics to intentionally increase the area burned under conditions when risks are acceptable to managers and fires can be used to achieve long-term restoration goals in fire adapted forests. We conducted experiments with the Envision landscape model to simulate increased levels of wildfire over a 50-year period on a 1.2 million ha landscape in the eastern Cascades of Oregon, USA. We hypothesized that at some level of burned area fuels would limit the growth of new fires, and fire effects on the composition and structure of forests would eventually reduce future fire intensity and severity. We found that doubling current rates of wildfire resulted in detectable feedbacks in area burned and fire intensity. Area burned in a given simulation year was reduced about $18 \%$ per unit area burned in the prior five years averaged across all scenarios. The reduction in area burned was accompanied by substantially lower fire severity, and vegetation shifted to open forest and grass-shrub conditions at the expense of old growth habitat. Negative fire feedbacks were slightly moderated by longer-term positive feedbacks, in which the effect of prior area burned diminished during the simulation. We discuss trade-offs between managing fuels with wildfire versus prescribed fire and mechanical fuel treatments from a social and policy standpoint. The study provides a useful modeling framework to consider the potential value of fire feedbacks as part of overall land management strategies to build fire resilient landscapes and reduce wildfire risk to communities in the western U.S. The results are also relevant to prior climate-wildfire studies that did not consider fire feedbacks in projections of future wildfire activity.
\end{abstract}

Key Words: Envision; forest landscape disturbance modeling; forest restoration; wildfire feedbacks; wildfire simulation; wildfire suppression policy

\section{INTRODUCTION}

Policies and planning efforts in the U.S. aimed at curbing wildfire impacts to social and ecological values increasingly recognize that current suppression policies are not financially sustainable and not desirable from an ecological standpoint (North et al. 2015, USDA OIG 2016). Spiraling suppression costs are eroding agency budgets allocated to restoration and conservation programs, and the effectiveness of suppression efforts to reduce the growth of extreme, long duration wildfire events is increasingly questioned (Calkin et al. 2015). The long-term effects of fire suppression policies and practices have led to widespread densification of firefrequent conifer forests and changes in fire regimes across much of the western U.S. (Arno and Brown 1991, Noss et al. 2006, Collins et al. 2013). Accelerated restoration programs (USDA FS 2012) are finding success in local contexts (USDA FS 2015a), but have not arrested the upward trend in burned area and risks to socioeconomic values. Changing the current trajectory in area burned by uncharacteristic fire in fire adapted forests, i.e., those with undesirable ecological consequences, will require more substantial reduction in fuels over wide areas to reduce the wildfire deficit throughout the western U.S. and change large scale wildfire behavior.

Newer U.S. federal wildfire policies have recognized that current mechanical fuel treatment programs alone are insufficient, and that safe and effective use of wildfire is a core part of long-term strategies to create fire adapted communities, fire resilient landscapes, and effective response to wildfire incidents (USDA/
USDI 2014). However, a major implementation challenge is defining and mapping the optimal mix of different long-term strategies to achieve risk management goals on dynamic, fireprone landscapes that are fragmented by ownership, ecological conditions, and attitudes toward fire (Fig. 12 in Ager et al. 2016). For instance, establishing a common agreement among land managers, landowners, and collaborative landscape planning groups (Jakes et al. 2007, Butler et al. 2015) concerning the spatial allocation of fire management strategies is a complicated process. In particular, managing natural ignitions versus traditional fuel management using mechanical thinning and underburning poses many challenges from a risk governance standpoint. Traditional fuel treatment methods can change the behavior of large fires and facilitate suppression and containment (Kalies and Yocom Kent 2016), particularly in areas treated with prescribed fire (Finney et al. 2007, Moghaddas et al. 2010, Syphard et al. 2011a, Stephens et al. 2012). However, mechanical fuel treatment programs are expensive and are constrained by administrative, financial, and operational factors (North et al. 2015). The scale of existing programs and associated investments would need to be increased by several orders of magnitude to treat the backlog of forests that have undergone densification and fuel buildup due to fire exclusion practices (Haugo et al. 2015).

By contrast, managing wildfires for restoration in fire-adapted conifer forests can be inexpensive (depending on suppression tactics), effective, and ecologically beneficial, but can carry high uncertainty and risk for human safety. Policy analyses must

${ }^{1}$ USDA Forest Service, Rocky Mountain Research Station, Missoula Fire Sciences Laboratory, ${ }^{2}$ Oregon State University, College of Forestry, Forest Ecosystems and Society, ${ }^{3}$ USDA Forest Service, Pacific Southwest Research Station, ${ }^{4}$ USDA Forest Service, Pacific Northwest Research Station, ${ }^{5}$ Oregon State University, College of Forestry, Forest Engineering, Resources and Management, ${ }^{6}$ Oregon State University, College of Agricultural Sciences, Biological and Ecological Engineering 
Fig. 1. Map of the study area showing (A) ownerships, towns, and major highways and (B) potential vegetation groups derived from Halofsky et al. (2014). BLM = Bureau of Land Management, USFS = U.S. Forest Service.
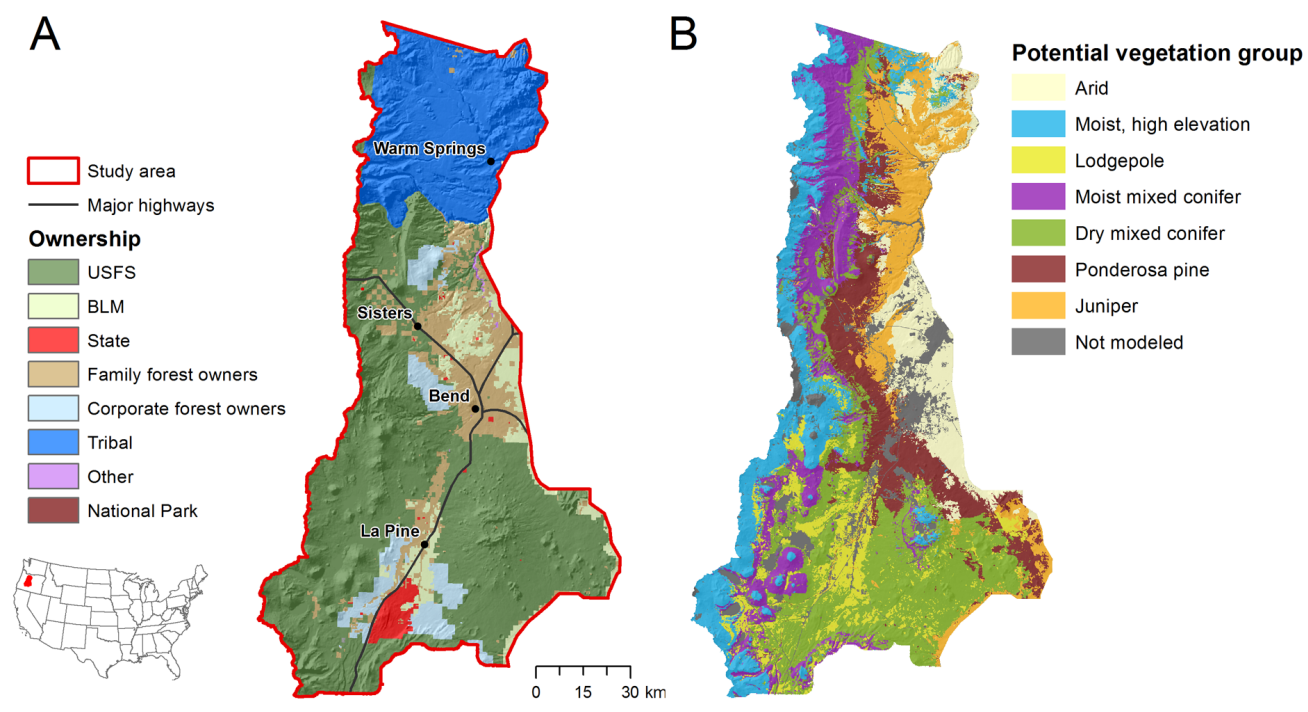

account for and mitigate the increased uncertainty and risks from fire events (Hill 2000, Wonkka et al. 2015, Hmielowski et al. 2016), which include unwanted aesthetics in amenity dependent communities, smoke production, and related health impacts. Numerous recent fires in the western U.S. have been managed in part or in whole for ecological benefit (henceforth "restoration fires"), including over 12 fires in 2017 totaling more than 60,000 ha of burned area (Forest Service Fire and Aviation Management, personal communication). Both modeling and empirical studies support these actions by showing that wild and prescribed fires can limit growth and lower severity of future fires and losses (Collins et al. 2009, Arkle et al. 2012, North et al. 2012, Houtman et al. 2013, Hoff et al. 2014, Parks et al. 2014, 2015a, Price et al. 2015) and facilitate suppression efforts (Moghaddas and Craggs 2007, Syphard et al. 2011b, Cochrane et al. 2012, Thompson et al. 2016). However, despite these and other studies, including landscape simulation research in which alternative fire management studies are simulated over time (Scheller and Mladenoff 2007, Spies et al. 2014), research is nonexistent on how landscape fire regimes and suppression budgets might change following long-term changes in fire policy. Thus the timing, pace, and scale of increased wildfire to actually achieve restoration goals are not known.

To address this gap, we use the agent-based Envision model (Bolte et al. 2004, Guzy et al. 2008) to examine the effects of increasing area burned on future fire regimes on a large 1.2 million ha multiowner landscape in the eastern Cascades of Oregon, USA. The area contains expansive areas of dry, fire adapted conifer forests that are the target of U.S. Forest Service restoration programs to improve fire resiliency and reduce wildfire impacts to local communities. We simulated four scenarios in which area burned was increased incrementally to mimic policies that leverage natural fires to reduce fuel loadings and restore presettlement fire regimes. We hypothesized that at some level of fire activity, fuels would begin limiting the growth of fires in subsequent years and reduce area burned and fire intensity because the consumption of fuels by wildfire would exceed accretion by forest growth and succession. We were specifically interested in evidence for tipping points (Adams 2013) and other discontinuities in fire feedbacks, and the overall leverage (Price et al. 2015) of fire to reduce future fire. We also hypothesized that increased fire would lead to impacts on ecological values including habitat for species dependent on specific types of old growth forest.

\section{METHODS}

\section{Study area}

The 1.2 million ha study area is located in central Oregon (Fig. 1) and includes public lands managed by the Deschutes National Forest (DNF), Bureau of Land Management (BLM), state of Oregon, National Park Service (NPS), and the Confederated Tribes of Warm Springs. Privately owned family lands and corporate timberlands, numerous small, private inholdings, and extensive wildland urban interface (WUI) are present on the east side of the study area (Table 1). The DNF is partitioned into about 30 different land management designations (e.g., general forest, scenic areas, recreation, wildlife, wilderness) according to the land and resource management plan (USDA FS 1990). Approximately $46 \%$ of the area within the DNF is in land designations that are available for forest and fuel management activities, with the unavailable lands located primarily within wilderness and recreational areas on the eastern edge of the forest.

The physiographic gradients, conifer forests (Fig. 1B), climate, and management resemble many of the western U.S. national forests and are described in detail elsewhere (Spies et al. 2014). Forest species include lodgepole pine (Pinus contorta), ponderosa pine (Pinus ponderosa), Douglas-fir (Pseudotsuga menziesii), white fir (Abies concolor), and mountain hemlock (Tsuga 
mertensiana). In general, the cooler, wet subalpine forests are located in the west, and semiarid juniper (Juniperus occidentalis) woodlands and arid shrublands to the east (Fig. 1B). About $24 \%$ of the study area contains dry mixed conifer forest, with lesser amounts of high elevation forest (15\%), ponderosa pine $(13 \%)$, and wet mixed conifer $(13 \%)$ forest. Juniper and lodgepole pine forests combined cover about $18 \%$ of the study area, with the remaining lands consisting of arid shrub steppe and nonvegetated areas $(17 \%)$. The area is noted for extensive contiguous stands of low-density ponderosa pine old growth that historically were maintained with periodic natural fire (Merschel et al. 2014). Much of the dry forest area receives extensive prescribed fire treatments by the DNF, although substantial areas with multilayer forests remain prone to uncharacteristically high intensity wildfire. The area has substantial fire activity, with on average 372 ignitions per year (1992-2013) that burn an average of 11,423 ha annually. Recent large fires include the B\&B Complex in 2003 (36,733 ha), Pole Creek in 2012 (10,844 ha), and Sunnyside Turnoff in 2013 (21,448 ha).

Table 1. Ownership types and corresponding proportion of the study area used in the simulation experiment.

\begin{tabular}{lc}
\hline \hline Ownership & Study area (\%) \\
\hline Federal & 61 \\
Tribal & 21 \\
Corporate forests & 6 \\
Family forests & 4 \\
State forests & 2 \\
Wildland urban interface (WUI) & 7 \\
\hline
\end{tabular}

\section{Envision overview}

Envision is a landscape and agent-based modeling platform that simulates landscape change over time with a plug-in architecture allowing the incorporation of submodels for landscape processes, such as vegetation succession, forest management, and wildfire (Fig. 2). The model and its application have been described in a number of papers (Guzy et al. 2008, Hulse et al. 2009, 2016, Barros et al. 2017, Spies et al. 2017) and we only briefly described them with an emphasis on the wildfire submodel. For additional details concerning the development and testing of the wildfire submodel see Ager et al. (2017) and Ager, Barros, Day et al. (unpublished manuscript).

\section{Vegetation succession}

Vegetation succession within Envision is simulated with a state and transition submodel that classifies the landscape into a discrete set of vegetation states, each state having a set of deterministic and probabilistic transitions that describe the vegetation trajectory over time in response to succession, disturbance, and management. The states were attributed to spatially explicit individual decision units (IDU) with size ranging between one and eight ha and delineated according to vegetation and administrative boundaries (Spies et al. 2017). The states and transitions we implemented were originally developed as part of the Integrated Landscape Assessment Project (ILAP; Halofsky et al. 2014) and modified to represent specific forest management activities and wildfire effects. Each IDU was attributed with a vegetation class (henceforth vegclass) that represented a unique combination of potential vegetation type (PVT), tree size, forest canopy cover, and canopy layering. There were a total of 39 potential vegetation types (Appendix 1, Table A1.1). Tree size was represented by nine classes ranging from barren to stands of giant trees ( $>76.2 \mathrm{~cm} \mathrm{dbh}$ ). Canopy cover was represented by five classes that ranged from none to high $(>60 \%)$, including a postdisturbance class. Forest canopy was classified as none, single, or multilayered. The structural stage attributes for describing a vegclass are further described in Appendix 1, Table A1.2 (see also Spies et al. 2017).

Fig. 2. Overview flow chart of wildfire scenario modeling showing the major "plugins" or submodels coupled to the Envision modeling framework. Wildfire events are simulated annually (left) using the FlamMap Application Programming Interface (API) as described in the text. Landscape potential fire behavior (flame length, spread rate) is calculated (right) using annual Envision outputs on landscape conditions that are processed through a command line version of FlamMap (C_FlamMap) as described in the text.

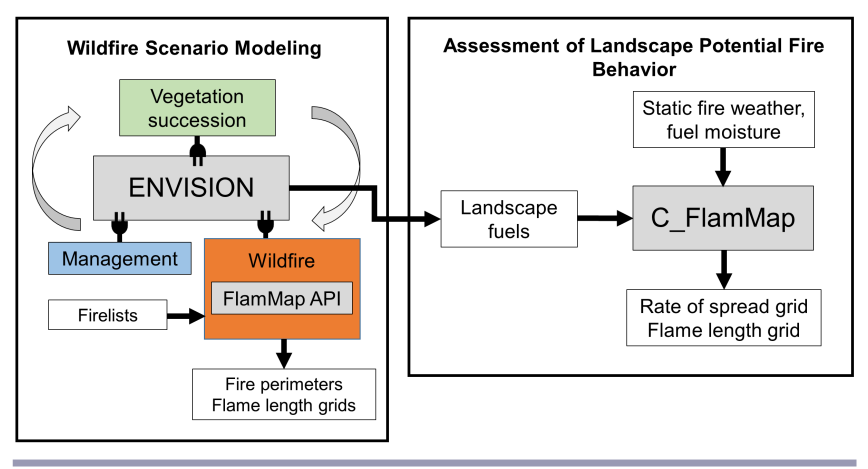

Each vegclass represented a vegetation state that can transition to a different state based on succession, management, and wildfire severity. State changes in vegetation were modeled as both probabilistic and deterministic transitions. Deterministic transitions were determined by an age threshold, meaning that once a specific age was reached, a stand would transition to a new successional state (Hemstrom et al. 2007). Probabilistic transitions reflected alternative succession pathways (e.g., a change in dominant species or development of seral species) and transition probabilities were determined by experts within the Forest Service and calibrated with the Forest Vegetation Simulator (FVS; Dixon 2002, Burscu et al. 2014). Transitions associated with management and wildfire were modeled as deterministic processes, through the management and wildfire submodels.

\section{Forest management}

Forest management activities were modeled in Envision based on extensive survey data and interviews with private landowners and public land managers, conducted as part of the Forests, People, Fire project (Spies et al. 2014). These management activities included various types of commercial and noncommercial harvesting, prescribed fire, and mowing and grinding (Appendix 2, Table A2.1). Management activities were simulated on the DNF and areas managed by the BLM following the Northwest Forest Plan and DNF land management plan (Appendix 2, Fig. A2.1). 
Specifically, treatments were not allowed in areas deemed unsuitable for commercial timber production (low productivity, not operable), or removed from the scheduled timber program because of biodiversity conservation and amenity protection (e. g., wilderness, recreation areas, critical habitat, scenic areas). The remaining $61 \%$ of the area was available for treatment, henceforth, treatable area.

Management activities were allocated to IDUs based on preference scores that considered both biophysical and forest stand information (see Barros et al. 2017). Individual decision units were selected for treatment in decreasing order of preference until the annual area treatment target was met for each treatment activity. Modeling management activities required grouping treatment units (IDUs) into project areas to replicate the spatial grain of operational implementation on national forests. For this purpose the "expand" function was created in Envision to build treatment blocks that approximated the size and distribution of historical management activities.

In our simulations, we specifically modeled a scenario that called for treating a total of 8500 ha per year, representing an annual rate of $0.7 \%$ of the study area, or $2.3 \%$ of treatable land on the DNF. The annual treatment area was distributed among the treatment types as follows: 50\% for mechanical thinning, 30\% for mowing and grinding, and 20\% for application of prescribed fire (some of which had previously been thinned). The effects of increasing management activity on wildfire dynamics are reported in Barros et al. (2017).

\section{Wildfire}

We created a wildfire simulation submodel within Envision (Fig. 2, left) by building an application programming interface to the FlamMap.DLL and Nodespread.DLL Dynamic Link Libraries developed at Alturas Solutions, Missoula, Montana (Brittain 2017). The resulting application programming interface (FlamMap API) shares the same code libraries as the FlamMap program (Finney 2006) and a number of wildfire decision support systems. The system has been extensively tested by the U.S. and international fire research community (Scott and Burgan 2005, Andrews 2007, Ager et al. 2011, 2014, Finney et al. 2011, NoonanWright et al. 2011, Kalabokidis et al. 2014, Salis et al. 2015, Oliveira et al. 2016). In-depth description of the fire model was beyond the scope of this journal and is described in detail in Ager, Barros, Day, et al., unpublished manuscript. A second command line program external to Envision (C_FlamMap, Fig. 2, right) was used to post process Envision landscape conditions and predict potential fire behavior for the entire study area (versus predicting and simulating discrete wildfire events). It was also built from FlamMap.DLL and Nodespread.DLL (Brittain 2017).

In each simulation year, Envision calls the wildfire submodel to prepare inputs by first translating the IDU conditions into surface and canopy fuels then writing a binary gridded $(90 \times 90 \mathrm{~m})$ input file for the wildfire submodel. The conversion process uses a grid template that contains topographic variables that remain unaltered through the simulation. The wildfire submodel then reads information on the fire ignitions from a firelist generated from a spatiotemporal ignition prediction model, including fire weather conditions and burn period. The wildfire submodel is executed to simulate all fires predicted for the current simulation year, and the resulting fire perimeter and gridded flame lengths are written to files. The flame length grids are overlaid with IDU polygons and the average flame length for each affected polygon is calculated and used to interpret fire effects.

Daily wildfire probability, ignition location, cause (human or natural), and fire size were predicted by a spatiotemporal ignition prediction model (Preisler et al. 2004, Preisler and Ager 2013) described in detail in Ager et al. (2017) and Ager, Barros, Day, et al., unpublished manuscript. The model uses empirically derived relationships between energy release component (ERC) and historical fire size and ignition location data (11,618 ignitions between 1992-2009) obtained from the spatial wildfire database of the U.S. (Short 2014). Energy release component is an index in the national fire danger rating system (Bradshaw et al. 1984) used for fuel moisture. Previous studies have successfully used ERC to predict wildfire occurrence and size at continental scales (Finney et al. 2011). The fire prediction system used ignition and ERC data for a 3.32 million ha region within central Oregon (henceforth region) that encompassed the study area (Ager et al. 2017). Historical daily ERC data were downloaded from the Remote Automated Weather (RAWS) USA Climate Archive (WRCC 2014) for 25 remote stations within the region and included data from 1961-2011 depending on the station. Variability in ERC values among the stations within the study area was not sufficient to warrant separate fire prediction models for the areas around each station, hence we averaged ERC values over all stations by day of year.

Fuel moisture files for each fuel size class (1-hr, 10-hr, 100-hr, 1000-hr; Scott and Burgan 2005), as well as live herbaceous and woody components, were derived from historical (1987-2011) average fuel moisture values for each fuel class and for each value of ERC used in the simulations. Fuel moisture files were created prior to running the simulation and read by the wildfire submodel as each fire was simulated.

Wind direction was generated by randomly selecting from historical gust directions (1994-2011) from the Lave Butte RAWS station based on day-of-year of the predicted fire. Wind speed was based on gust values derived from the same weather data, but was restricted to days in the historical record in which area burned exceeded 500 ha to capture days in the historical record when fires actively spread. Wind gust speed was sampled from a gust speed probability distribution generated from analysis of the Lava Butte RAWS data.

The Nodespread.DLL fire spread algorithm requires burn period rather than fire size (Finney 2002), therefore fire size was translated from hectares to minutes by generating a fire size-burn period distribution using the wildfire submodel. Random ignition point locations (100) were simulated in the study area with burn periods ranging from 30 to $8000 \mathrm{~min}$, with wind speed, azimuth, and ERC fixed at $18 \mathrm{mph}, 220$ degrees, and 60, respectively (Ager, Barros, Day, et al., unpublished manuscript). With these data, we derived a second-order polynomial linear regression model that was used to predict burn period for each fire as a function of modeled fire size (Ager, Barros, Day, et al., unpublished manuscript). Preliminary examination of the relationship showed calibration procedures were needed to replicate historical fire size distributions. Specifically, if the fire size was under predicted in Envision because ignitions landed in nonburnable areas, a fire size 
adjustment was made to randomly relocate ignitions within a 5 $\mathrm{km}$ radius of the original location. This was done up to five times for any ignition that did not reach $80 \%$ of its predicted size. The $\mathrm{XY}$ location of the fire that best matched the predicted size was recorded in the output firelist. When the simulated fire size in Envision was overestimated (greater than 1.5 times the predicted size) the burn period was reduced proportionally to the difference between the predicted and simulated fire size (Ager, Barros, Day, et al., unpublished manuscript).

The spatiotemporal ignition prediction model was written in $\mathrm{R}$ (R Core Team 2014) and executed prior to an Envision simulation to generate firelist text files that predicted daily fire occurrence and size from the model. Additional parameters associated with each ignition in the firelist are day-of-year, ERC, fire weather parameters (wind speed and azimuth), burn probability, burn period, fire cause (natural or human), ignition location (XY coordinate), and fuel moisture conditions. Note that the spatiotemporal ignition prediction model generated a stream of ERCs based on an autoregressive model of historical ERCs, and thus each execution resulted in a unique firelist and 50-year fire simulation.

\section{Fire effects}

Fire effects were modeled using gridded flame length outputs for each fire perimeter generated by the wildfire submodel. Flame length is often used as a proxy for describing fire intensity in the field (NWCG 2013). A fire effects lookup table translated flame lengths into disturbance types for each vegclass affected by fire. Flame length was translated into three fire disturbances: (1) lowintensity fires that do not cause enough tree mortality to change the vegclass, but reduce fuels accumulation; (2) mixed severity fires that may change the vegclass through the mortality of smaller trees and/or less fire resistant species; and (3) stand-replacing fires that kill all trees, returning the IDU to either a grass-forb state, or when sprouting species are present, to a young state. The translation of flame length to fire severity relied on FVS (Reinhardt and Crookston 2003). In this process, we used the approach of Ager et al. (2010) in which representative tree lists for each vegclass were exposed to simulated fires of increasing flame length in $0.33 \mathrm{~m}$ intervals and the flame length interval that resulted in more than $20 \%$ and less than $80 \%$ tree mortality in the stand was used to establish the lower and upper flame length thresholds for mixed severity fire. Flame lengths above and below the mixed severity threshold were then used to classify fires as stand-replacing and low severity, respectively.

\section{Fuel dynamics pre- and postdisturbance}

Surface and canopy fuels consisted of the standard five fuel variables used by FlamMap5 and related wildfire simulation models (Finney 2006, Ager et al. 2011, Finney et al. 2011). Surface fuels were represented by the fuel models of Scott and Burgan (2005). Surface fuel models for the IDUs in the DNF were assigned based on the majority representation in the forest's fuel model layer. Outside the forest, we used the LANDFIRE 2008 rapid refresh FBFM40 layer (LANDFIRE 2013). Canopy fuels were described by canopy bulk density, canopy cover, canopy base height, and total stand height, and determined using the average value of each variable for representative stands for each vegclass with the Fire and Fuels Extension (FFE) of FVS.
Changes in fuel structure that were not accompanied by changes in vegclass (e.g., tree size or canopy) were accomplished by assigning fuel-model variants based on disturbance type (Appendix 2, Table A2.2). The fuel model variant remained unchanged until a set number of years passed (time-in-variant) or a vegclass deterministic or probabilistic transition occurred. The impact of management activities on vegclasses was estimated based on expert opinion (Platt 2014, Kline et al. 2017) and stand modeling with FVS. For example, tree removal (i.e., thinning, clear-cut) triggered transitions to vegclasses that reflected lower tree density, larger tree size, lower canopy closure, and reduced canopy layers, depending on the intensity of the management activity (Appendix 2, Table A2.1). For management actions that resulted in changes in surface fuel attributes only (e.g., fuels mastication, prescribed fire, and surface fire), the vegclass remained unchanged.

\section{Simulations}

We used the wildfire submodel within Envision to simulate 50year scenarios where wildfire activity was first simulated at contemporary levels (1992-2009), and then incrementally increased while maintaining forest and fuel management at current levels (Barros et al. 2017). The four increased levels of wildfire activity were achieved by multiplying the burn period of each ignition by $2 \mathrm{X}, 3 \mathrm{X}, 4 \mathrm{X}$, and $10 \mathrm{X}$. For each of the five scenarios we simulated 15 replicates and varied only the burn period. A number of other fire simulation parameters could have been manipulated to achieve an increase in area burned (fuel moisture, wind speed) although changes in these parameters could potentially also increase fire intensity as well.

\section{Fire feedbacks}

We used the simulated fire perimeter data to examine the selflimiting properties of wildfires over time. We analyzed total area burned per year by fitting a generalized additive model (GAM; Wood 2011) using seven explanatory variables: ERC, wind speed, burn period, the cumulative area burned in prior years, year of simulation (1-50), average flame length, and wildfire scenario (1X, $2 \mathrm{X}, 3 \mathrm{X}, 4 \mathrm{X}, 10 \mathrm{X})$. We considered four alternative time lags for cumulative area burned in prior years: $1-5$ years, $6-10$ years, $11-20$ years, and more than 20 years. The model was run using the Mixed GAM Computation Vehicle (mgcv) package (Wood 2006) in R ( $\mathrm{R}$ Core Team 2014). The resulting model was used to estimate the fractional change in area burned in a given simulation year in response to prior area burned, expressed as a proportion of the study area. We also examined how the effect of prior area burned varied over time. We estimated the combined effects of year and cumulative area burned on area burned in a given year, and created smoothed contour plots. Outputs from the statistical modeling were also used to estimate the wildfire leverage, meaning the unit reduction in area burned in a given year resulting from one unit of antecedent area burned. The concept of leverage has been used to quantify the effect of prescribed fire on subsequent unplanned fires (Price et al. 2012, 2015).

To examine changes in fire intensity and spread rate for the entire study area, we processed landscapes generated by Envision with C_FlamMap to calculate potential flame length and spread rates under static fuel moisture and weather (Fig. 2, right). C_FlamMap (Brittain 2017) is a command line version of 
Table 2. Wildfire response metrics per wildfire scenario over 50 simulated years. Increased levels of wildfire activity in each scenario were achieved by multiplying the burn period of each ignition over contemporary levels by the multiplier indicated.

\begin{tabular}{|c|c|c|c|c|c|}
\hline \multirow[b]{2}{*}{ Wildfire response metric } & \multicolumn{5}{|c|}{ Wildfire scenario } \\
\hline & $1 \mathrm{X}$ & $2 \mathrm{X}$ & $3 X$ & $4 \mathrm{X}$ & $10 \mathrm{X}$ \\
\hline Total area burned (ha) & $3,350,622$ & $8,702,019$ & $13,650,813$ & $18,170,496$ & $38,509,509$ \\
\hline Total area burned per replicate (ha) & 223,375 & 580,135 & 910,054 & $1,211,366$ & $2,567,301$ \\
\hline Average annual area burned per replicate (ha) & 4467 & 11,603 & 18,201 & 24,227 & 51,346 \\
\hline Average fire size (ha) & 325 & 847 & 1333 & 1782 & 3825 \\
\hline $\begin{array}{l}\text { Simulated increase in area burned over } \\
\text { contemporary }(\%)\end{array}$ & 0 & 253 & 407 & 542 & 1150 \\
\hline Study area burned per replicate year ${ }^{-1}(\%)$ & 0.4 & 1.0 & 1.6 & 2.1 & 4.4 \\
\hline FRI (year) $)^{\dagger}$ & 250 & 100 & 63 & 48 & 23 \\
\hline Leverage ${ }^{*}$ & 0.01 & 0.6 & 0.15 & 0.21 & 0.43 \\
\hline
\end{tabular}

${ }^{\dagger} \mathrm{FRI}=$ fire rotation interval, the time required to burn the entire study area landscape.

teverage corresponds to the slope of a linear regression where the independent variable is annual area burned and the predictor is cumulative area burned in the previous five years.

FlamMap5 and calculates independent potential fire behavior for each pixel assuming static weather conditions. We processed 3750 simulations ( 15 replicates $\mathrm{x} 5$ wildfire scenarios $\mathrm{x} 50$ years) with C_FlamMap to generate flame length $(\mathrm{m})$ and spread rate $(\mathrm{m}$ $\mathrm{min}^{-1}$ ) grids at $90 \mathrm{~m}$ resolution. We used $97^{\text {th }}$ percentile weather conditions to represent extreme weather conditions consistent with large fire growth in the area (Ager et al. 2007). The outputs were used to calculate and plot average flame length and average rate of spread over the entire forested area (and 15 replicates), per year and fire scenario.

Finally, to understand how increasing levels of fire affected fire sensitive components of biological diversity, we assessed changes in high suitability habitat for the northern spotted owl (NSO). The NSO is listed under the Endangered Species Act in the Pacific Northwest and large reserves in the study area are dedicated to maintaining and growing habitat that consists of dense, multilayered, older mixed-conifer forests. The habitat model was based on vegetation type, canopy cover, and tree size characteristics and was developed specifically for central Oregon using owl occurrence data as reported by Spies et al. (2017).

\section{RESULTS}

Analysis of area burned among the wildfire scenarios showed that increasing the wildfire activity from $1 \mathrm{X}$ to $10 \mathrm{X}$ resulted in an increase of average annual area burned from 4467 (0.4\% of study area) to 51,436 ha ( $4.4 \%$ of study area; Table 2$)$. Note that because of the nonlinear behavior of fire spread, the increase in burned area relative to contemporary wildfire is not proportional to the burn period multipliers (Appendix 3, Fig. A3.2), e.g., increasing the burn period by a factor of 4 led to an increase in area burned by a factor of 5.4 (Table 2). In the contemporary scenario, the fire rotation interval (time to burn the study area) was 250 years versus 23 years for the 10X scenario (Table 2). The effect of increasing burn period was especially apparent in the arid, juniper woodland and dry forest areas compared to moist mixed conifer and subalpine forests (Fig.1). The 10X wildfire scenario resulted in fire perimeters that eventually covered almost the entire study area (Fig. 3E). Annual variability in area burned was greater for scenarios with higher levels of simulated fire (e.g., 4X and 10X) and mean fire size increased substantially from an average of 325 ha to 3732 ha for the $1 \mathrm{X}$ and $10 \mathrm{X}$ scenarios, respectively (Table 2; Fig. 4).
Fig. 3. Simulated fire perimeters in the study area from one 50year Envision simulation for five wildfire scenarios: $1 \mathrm{X}(\mathrm{A}), 2 \mathrm{X}$ (B), 3X (C), 4X (D), and 10X (E). Increased levels of wildfire activity in each scenario were achieved by multiplying the burn period of each ignition over contemporary levels by the multiplier indicated.
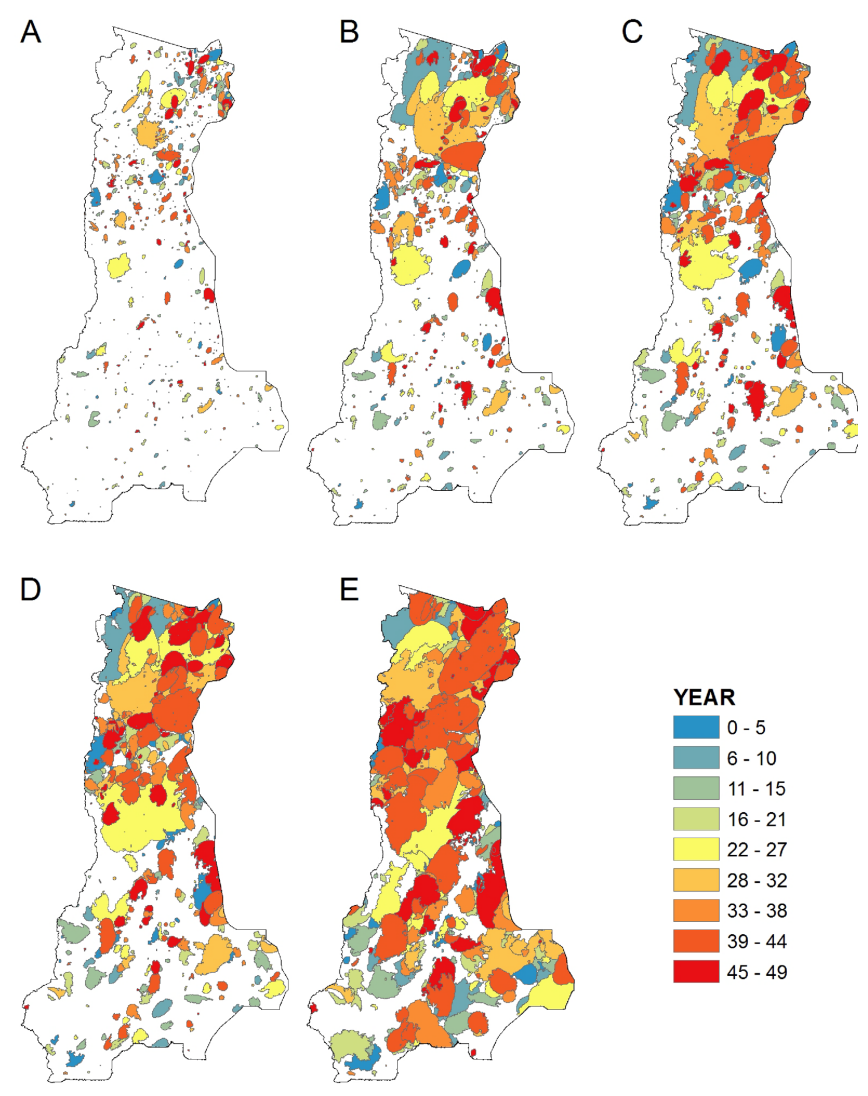

Specific instances in which fire growth was limited by prior fires during the simulation were readily apparent in the simulation outputs. For the purpose of illustrating fire interactions, we identified two fire perimeters in an Envision simulation in which 
Fig. 4. Mean fire size by year of simulation for 15 replicate runs for each wildfire scenario (1X, 2X, 3X, 4X, 10X, and see Table 2 for total area burned per year in each scenario). Increased levels of wildfire activity in each scenario were achieved by multiplying the burn period of each ignition over contemporary levels by the multiplier indicated.

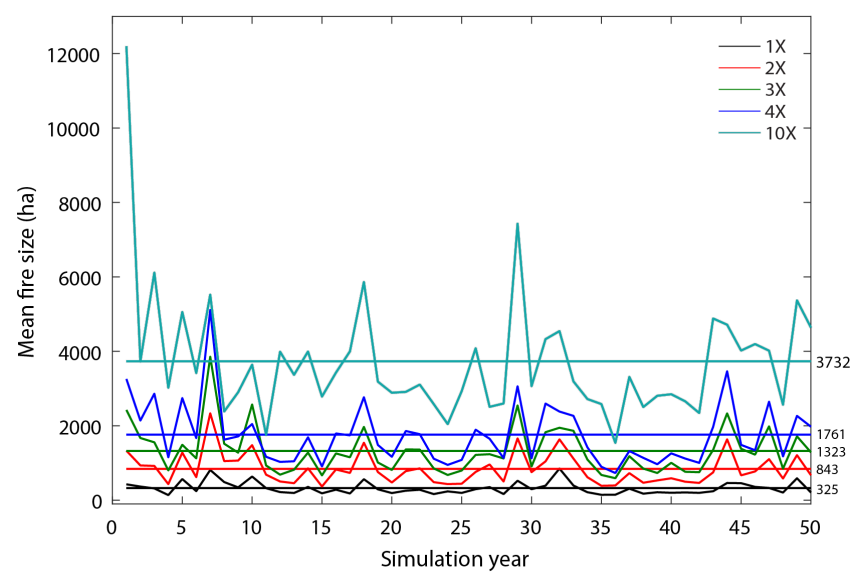

a simulated fire encountered the perimeter of a fire that had burned the prior year (Fig. 5). These two ignitions were separated by three years and the first fire reduced the area of the second fire by $30 \%$. In the 50 -year simulation, the cumulative effect of these interactions over space and time showed that the effect of prior area burned on wildfire size in the current simulation year depended on the time window between the fires (Fig. 6). Fires burning in the past five years reduced area burned in the current simulation year up to $80 \%$ under the extreme case when $60 \%$ of the study area was burned (Fig. 6A). Fires burning in the past 10 years reduced the area burned in a given simulation year a maximum of $35 \%$. Diminishing returns in terms of the effect of prior area burned on subsequent fires in a given year were observed when about $35-45 \%$ of the landscape was burned in the previous 10 years (Fig. 6A, B). Wildfires more than 10 years prior had no discernible effect on the area burned in a given simulation year (Fig. 6C, D). Over all the scenarios, we estimated the average reduction (or leverage; Price et al. 2012, 2015) of area burned in the prior 5 years on area burned in a given simulation year was about 0.18 (i.e., $18 \%$ reduction per unit area burned), and varied from 0.01 for the $1 \mathrm{X}$ scenario to 0.4 for the $10 \mathrm{X}$.

The effect of prior area burned on subsequent area burned varied over time and generally followed the annual rate at which wildfires burned the study area (Fig. 7). For example, when $50 \%$ of the study area was burned over the first 10 years of the simulation ( $5 \%$ per year, 20 year fire rotation), about $0.7 \%$ of the study area was predicted to burn in any subsequent year. When the same area was burned over the prior 50 years (1\% per year or fire rotation of 100 years), the rate of burning in year 50 was estimated between $2.2 \%$ and $2.7 \%$, or about 3 times higher (Fig. 7). We observed similar results for rates of spread confirming that observed effects on burned area were caused by modification of fuels from prior area burned (Appendix 3, Fig. A3.1). Specific thresholds for discontinuities in fire feedbacks were not observed,
Fig. 5. Example of fire feedbacks in the study area in which a simulated fire (A) in simulation year 25 limited the growth of a subsequent fire in year 28 (B). Pixels represent flame length from a low of 1 (green) to high of $54 \mathrm{~m}$ (red). Arrows indicate direction of fire spread. Fire in A was 14,657 ha and simulated at $\mathrm{ERC}=80$ and wind speed $=18 \mathrm{mph}$. Fire in $\mathrm{B}$ was 8609 ha at $\mathrm{ERC}=81$ and wind speed $=16 \mathrm{mph}$. Fire $\mathrm{B}$ without $\mathrm{A}$ burned 12,286 ha.

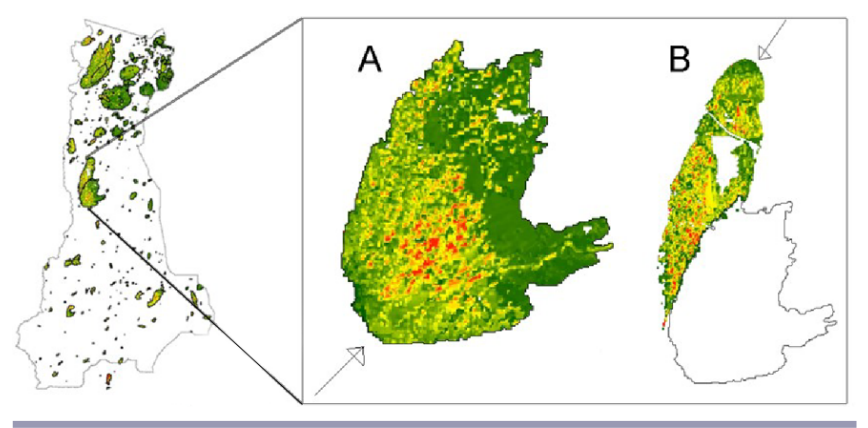

Fig. 6. Change in average area burned in any given year as a function of area burned in the previous 5 years (A), 6 to 10 years (B), 11 to 20 years (C), and more than 20 years (D).
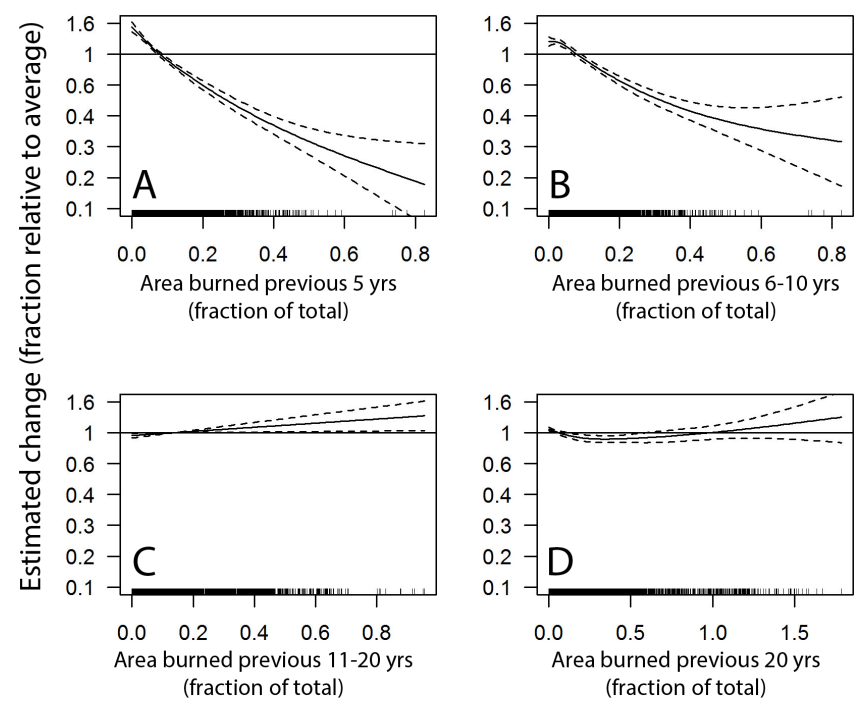

but the analysis did reveal cyclical trends in fire feedbacks with increasing area burned. The cycles exhibited a periodicity of about 10 years (Fig. 7), corresponding to the regrowth of fuels as determined by the vegetation succession submodel.

Although contours of the estimated effect ( $\%$ burning in current year, shown in Fig. 7) more or less paralleled the rate of burning (or fire rotation interval, Fig. 7; Table 2), there was a general tendency for the effect to diminish over time, meaning a higher rate of burning was required to achieve the same effect in later versus earlier simulation years. For instance, at a $2.5 \%$ rate of annual burning (fire rotation interval of 40 years) after 20 years 
(Fig. 7, $\mathrm{X}=$ year 20, $\mathrm{Y}=50 \%$ ), the estimated rate of burning for subsequent years is estimated at ca. $1.7 \%$ per year. At the same rate of burning over a longer time frame (Fig. 7, X = year 40, Y $=100 \%$ ), the estimated rate of burning for subsequent years is about $1.4 \%$ or a $18 \%$ decrease in the annual area burned. A decreasing effect of prior burned area on the area burned in a given simulation year is a positive feedback of fire on fire, and although this longer-term effect was minor compared to the shortterm effects of prior burned area (Fig. 5A), it was observed for a wide range of fire rotation intervals in the simulation outputs.

Fig. 7. Contour plot of expected area burned in the current year $(\%$ total) conditional on simulation year and cumulative area burned in all previous years. Black lines show reference fire rotation intervals, or number of years to burn an area equal to the entire study area. The average area burned per year for all simulations was $2.2 \%$ or a fire rotation of about 45 years. Contours show a 10 -year periodicity that corresponds to the modeled vegetation regrowth after fires.

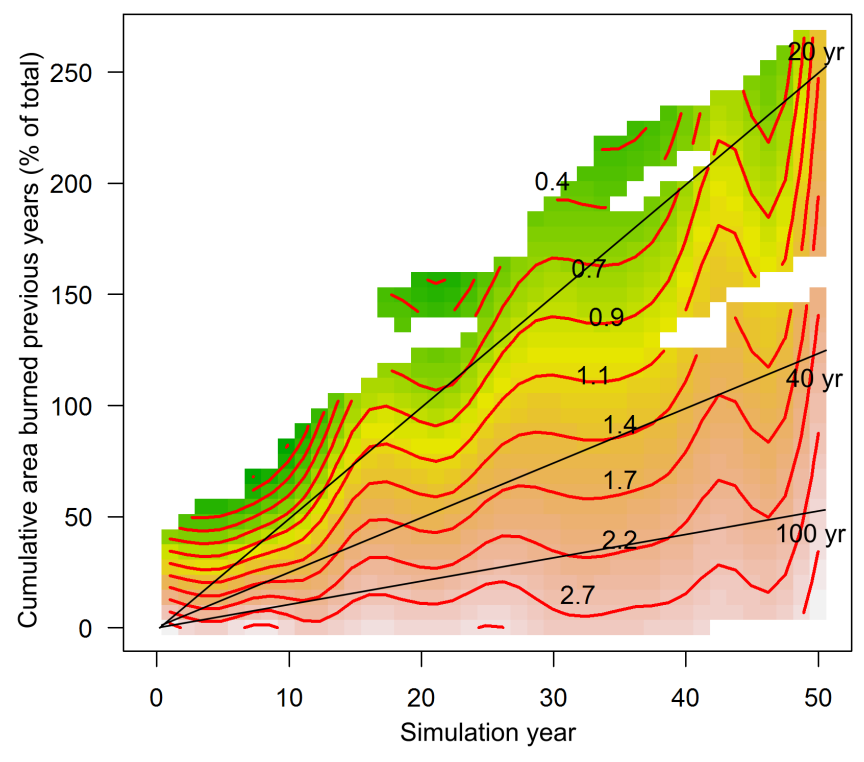

Modeled outputs of potential fire behavior for the study area as a whole obtained from C_FlamMap simulations showed how fire intensity and spread rate changed with increasing levels of fire activity (Fig. 8A, B). As noted earlier, these results represent potential fire behavior if the entire study area burned under constant weather conditions, versus simulated fire events within Envision. Trends in potential fire behavior over time measure broad-scale changes in surface and canopy fuels. Substantial reductions in potential flame length were observed as fire activity was increased (Fig. 8A). For instance, average flame length decreased in the $10 \mathrm{X}$ scenario from $6 \mathrm{~m}$ in year 1 to $2.3 \mathrm{~m}$ in year 50 (62\% reduction) with most of the change occurring in the first 10 years of simulation. A slightly upward trend in flame length was observed over time for the contemporary $1 \mathrm{X}$ fire scenario in the first 10 years of the simulation (Fig. 8A). Fire intensity decreased slightly for the $2 \mathrm{X}$ scenario and more sharply for the higher levels of burning suggesting that reducing the upward trend in the contemporary scenario would require at least twice the current area burned. Changes in potential rate of spread over time mirrored flame length although the effect of increasing fire was less pronounced. For the $10 \mathrm{X}$ scenario, rate of spread was reduced from $5.4 \mathrm{~m} \mathrm{~min}^{-1}$ to $3.2 \mathrm{~m} \mathrm{~min}^{-1}$ at the end of the simulation time ( $40 \%$ reduction over 50 years) with most of the reduction observed in the first 10 years of the simulation (Fig. 8B).

Fig. 8. Trend in (A) potential flame length, (B) potential rate of spread, (C) northern spotted owl habitat (NSO), and (D) standreplacing fire by simulation year and wildfire scenario (1X, $2 \mathrm{X}$, $3 \mathrm{X}, 4 \mathrm{X}$, and 10X). Increased levels of wildfire activity in each scenario were achieved by multiplying the burn period of each ignition over contemporary levels by the multiplier indicated.

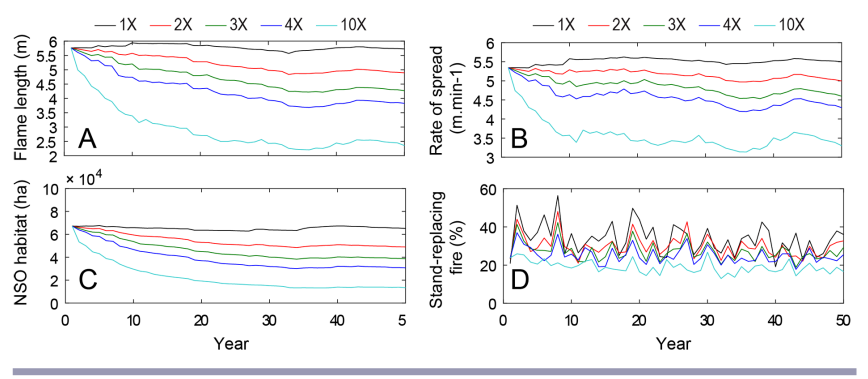

Northern spotted owl habitat (NSO) declined slightly (2000 ha, $3 \%$ ) under the $1 \mathrm{X}$ fire scenario (Fig. 8C). Substantial reduction was observed for the $10 \mathrm{X}$ scenario in which NSO habitat was reduced by 36,474 ha $(80.13 \%)$. Intermediate fire scenarios also resulted in substantial decline in habitat area, and for all scenarios much of the loss occurred in the first 20 years. In the $10 \mathrm{X}$ wildfire scenario, most of the decline occurred in the first 10 years of the simulation. The decline was spread more widely over the simulation time in the other fire scenarios.

Fire severity among the scenarios was measured as the percentage stand replacing fire in forested areas (i.e., high severity), versus mixed and low severity (Fig. 8D). There was a slight trend over time toward less stand-replacing fire in all the scenarios. However, the differences among scenarios were larger than the downward trend over time. Stand replacing fire relative to total area burned averaged $34 \%$ for the $1 \mathrm{X}$ scenario, compared to $19 \%$ for the $10 \mathrm{X}$ or a $44 \%$ reduction.

\section{DISCUSSION}

Our study examined the effects of increased fire on future fire regimes and forest structure on a 1.2 million ha landscape in central Oregon. We examined whether contemporary (prior 20 years) fire regimes are stationary and what magnitude of burning would be required to observe fire feedbacks under current forest management programs. Negative fire feedbacks were defined as the reduction in area burned by wildfire events in a given year resulting from encounters with prior wildfire perimeters. We found that feedbacks paralleled the rate of burning during the 50year simulation and that increasing wildfire reduced landscape flammability as measured by spread rate, flame length, and area burned. On average, we found that area burned in a given simulation year was reduced by about $18 \%$ per unit area burned within the prior five years averaged across all scenarios. At the highest fire treatment (10X burn period, $11.5 \mathrm{X}$ area burned), the study area burned with a fire rotation interval of 23 years, versus 250 years under the simulated contemporary rate of burning. 
Averaged over the different vegetation types, area burned more than 10 years prior did not significantly affect the area burned in a given simulation, a result that is within the range of longevity ( 2 to 23 years) reported in a recent review (Prichard et al. 2017). Negative fire feedbacks were slightly moderated by longer-term positive feedbacks, in which the effect of prior area burned diminished during the simulation.

The broader interpretation of the results is in part conditional on the plausibility of the accelerated fire scenarios, which could materialize by multiple pathways including: (1) a warming climate (McKenzie et al. 2004, McKenzie and Littell 2017); (2) a change in suppression practices (USDA/USDI 2009); and (3) increased human ignitions. McKenzie et al. (2004) used statistical relationships between climate and wildfire activity to estimate that a moderate warming scenario could result in a two to fivefold increase in annual area burned in the western U.S. However, this and related studies assumed fuels would be available at future rates of burning and thus fuel-mediated fire feedbacks were not factored into the estimates (see McKenzie and Littell 2017). Although climate-fire statistical studies have provided evidence that fire regimes in and around the study area are strongly driven by climate (not fuel limited), our study suggests that under a warmer climate, higher rates of burning would be moderated by negative fire feedbacks. We also showed that future fire regimes would be characterized by predominately low intensity wildfire (Fig. 8A). Achieving our wildfire scenarios through changes in current suppression practices is a social and operational question that is difficult to assess. Current federal wildfire policy provides for many options to respond to wildfire ranging from full suppression to passive monitoring (USDA-USDI 2009), but risk considerations, including potential impacts to socioeconomic values located on national forests have generally lead to a full suppression response on the vast majority of wildfires in this region. The potential for human ignitions to accelerate wildfire activity in the study area deserves further consideration because they account for about half of the historical area burned in the past 20 years. Human ignitions have effectively extended the fire season into the spring and fall, and probably contribute more to area burned by low severity fire than natural ignitions (Fig. 4 in Ager et al. 2017). Our Envision model does include projections of population growth within the study area, but we did not model how this change affected ignitions as done elsewhere (Prestemon et al. 2016).

A number of empirical studies have shown reduced wildfire spread and severity in recently burned areas (Teske et al. 2012, Haire et al. 2013, Prichard and Kennedy 2014, Parks et al. 2015b, Holsinger et al. 2016). Despite these and other studies of fire on fire feedbacks (reviewed in Prichard et al. 2017), a mechanistic typology to disentangle underlying processes that generate both positive and negative feedbacks could help organize existing knowledge and the design of future studies. For instance, Pritchard et al. (2017) tabulated four metrics that describe potential outcomes from fire-on-fire interactions that could be further expanded by considering spatial mechanisms by which these effects are manifested. Specifically, ignitions can occur in recently burned areas and fail to spread, thus changing patterns of fire occurrence (Parks et al. 2015c). Ignitions in recently burned areas with decreased fuel loadings can result in fires with lower spread rates and intensity (Safford et al. 2009, Prichard et al.
2010). Finally, fires can ignite in unburned areas and spread to burned areas (Finney et al. 2005). Previous studies have not been able to distinguish the relative contributions of these different spatial interactions because of lack of data, small sample sizes, or a combination of the two. In general empirical data sets have insufficient information to understand and analyze the simultaneous effects of past fires on spread rate, intensity, and burned area over long periods of time, hence the utility of a simulation framework. As an example, we observed short-term ( $<10$ years) negative feedbacks stemmed from fires encountering recently burned area (Fig. 3E, Fig. 5) whereas longer-term positive feedbacks resulted from fire-induced accelerated succession in which the landscape changed from relatively stable mature vegetation states to younger successional stages that have rapid transitions to increasingly flammable conditions. Positive fire feedbacks are not reported for temperate forests in the review by Pritchard et al. (2017). Our future work will include analyses to determine the relative effects of the different mechanisms that contribute to fire feedbacks, both positive and negative, observed within the study area.

We examined the ecological impact of our fire scenarios using habitat for northern spotted owl (NSO) and area burned by high severity fire. Large reductions in NSO habitat were predicted by the model under scenarios with accelerated wildfire (Fig. 8C). Habitat for the NSO is sensitive to fire, owing to the fact that requirements for high levels of canopy closure and multistory conditions translate to high crown fuel loadings and ladder fuels, and thus the potential for high severity fire. Prior simulation studies suggest that even low intensity fire can modify stand structure in NSO habitat to make it unsuitable (Ager et al. 2007, Kerns and Ager 2007). In the companion study of Spies et al. (2017), wildfire was the major driver of habitat loss although contemporary fire levels slightly increased habitat over time as observed in our study. Dense older forests also provide habitat for other species of interest including the northern goshawk (Accipter gentilis) and Pacific marten (Martes caurina) (Spies et al. 2017). Northern spotted owls are a federally listed species (ESA 1973), and as pointed out by Spies et al. (2017), their habitat preservation is an ecological and social driver of federal forest management at the expense of other ecological and socioeconomic values (e.g., open old growth forests that are more resilient to fire and drought). In this study, a clear trade-off existed between increased fire activity to restore fire resilient forests and the conservation of NSO habitat. For instance, U.S. Forest Service managers are increasingly focused on managing for historical disturbance regimes and ranges of variability (Haugo et al. 2015). Although areas of dense multilayered forests were preserved under historical fire regimes because of their topographic positions and climate (Camp et al. 1997), accelerated wildfire scenarios we simulated burned through these areas. Refining the simulations to increase the frequency of lower severity fire specifically could lead to the development of forest structure and composition that is resilient to fire and climate change (Hessburg et al. 2016). Although Davis et al. (2016) found that NSO habitat in the eastern Cascades of Oregon actually increased by 13\% between 1993 and 2012, a single large fire within the study area could reverse this trend. Spies et al. (2017) found that NSO nesting habitat declined under management scenarios compared to those without management, although contemporary wildfire levels resulted in higher habitat loss than did management. 
The study complements previous forest and fire modeling studies, although comparisons are difficult. Barros et al. (2017) examined increasing levels of fuel management and found that, compared to no action, current forest management policy on federal lands led to reductions in area burned up to $25 \%$ over a period of 50 years. They also found that tripling the current amount of area treated would reduce burned area under simulated conditions up to $40 \%$, and the likelihood of a fire $>10,000$ ha by threefold. The "leverage" (Price et al. 2015) we found of prior area burned on current year fire activity was less than typically reported for fuel treatments (Finney et al. 2007). We suspect that leverage from fuel management is more efficient because fuel treatments are dispersed and provide a higher chance of encountering a subsequent fire compared to a single fire footprint. Empirical studies have shown that management policies allowing fires to burn in wilderness areas or use of prescribed fire have eventually led to self-limiting fire in specific fire-on-fire events (Finney et al. 2005, Boer et al. 2009, Price et al. 2015). Other simulation studies (e.g., Loudermilk et al. 2014) did not report landscape fire feedbacks, presumably because fires rarely intersected prior fire perimeters. Price et al. (2012) found zero leverage in southern California in predominantly grassland-shrubland systems likely due to low encounter rates (intersection of wildfire with previously burned areas), and noted higher leverage in forests and savannas in Australia (0.1 and 0.3, respectively). In a subsequent global analysis (Price et al. 2015), the highest leverage was documented in Portugal (0.9). This high rate was partially explained by likely spatial bias, in which the complex, fragmented landscape constrains fire spread and leads to regular reburning.

Exploring future trade-offs associated with a fire management strategy that relies on both restoration fires and mechanical fuel management requires a robust landscape and management simulation model. Specifically, national forests could benefit from mapping landscape-scale synergies between mechanical forest fuel treatments and restoration wildfires to meet ecologic, socioeconomic, and fire resiliency goals of federal forest restoration programs. Optimal investment levels likely exist for respective management emphases on mechanical fuel management, prescribed fire, and restoration wildfires. For instance, fuel management programs can be used to build low hazard wildfire containers in which fires can burn at low intensity and be contained with low-cost suppression activities. Much of the landscape fuel management research has explored optimal fuel management strategies to specifically reduce fire spread (Loehle 1999, Finney 2007, Lehmkuhl et al. 2007, Parisien et al. 2007, Konoshima et al. 2008, Wei et al. 2008, Kim et al. 2009), versus creating fire adapted (e.g., low hazard) landscapes that can be maintained as resilient landscapes with periodic fire. However, treating landscapes to restore natural fire is appropriate in fire adapted forests, whereas fuel break strategies aimed at fire exclusion and protecting fire sensitive values (e.g., WUI or habitat for dense forest species) serve a purpose in high severity fire regimes. Current fuel management projects on western U.S. national forests are difficult to interpret with respect to long-term fire management goals (exclusion versus acceleration) most likely because they are motivated by wide ranging objectives including economic values, fire ecology, current wildfire exposure, and stakeholder involvement in the planning process (Butler et al. 2015, Kalies and Yocom Kent 2016).
Ultimately the development of policies to address socioeconomic and ecological losses from large-scale natural disturbances is a complex problem that requires the integration of both social and biophysical risk systems (Corotis and Hammel 2010, Fuchs et al. 2011). Reducing the area of high-severity fire through fuel management or wildfire to create fire resilient forests comes with a number of trade-offs in terms of addressing the production of other ecosystem services and socioeconomic demands from national forests. Fire suppression costs, which are currently over $50 \%$ of the USDA Forest Service annual budget (USDA FS $2015 b$ ), can potentially be reduced by restorative fire, however, water quality, wildlife, recreation, and visual amenities will be affected in the short run if natural ignitions are allowed to burn as natural fires develop fire resilient forests. Fire interactions are highly uncertain in space and time, and thus scheduling wildfire as a way to treat fuels is a complicated approach compared to fuel treatments, especially within highly fragmented landscapes with respect to ownership, development, and disparate land management objectives (Charnley et al. 2017). In addition, increased smoke production from restoration wildfires has serious health implications and degrades amenity values in rural communities that depend on them for economic sustainability (Liu et al. 2015, Schweizer and Cisneros 2017). An equally large challenge will be managing the social and political risk facing fire managers if fires escape and result in economic losses from either restoration wildfires or prescribed fire (Hill 2000, Ryan et al. 2013). Despite improvements in the technology and tools to predict the spread of wildfires during an active fire incident (Noonan-Wright et al. 2011), high uncertainty and risk for managers during wildfire events will remain a barrier to using wildfires to manage fuels, especially near the urban interface and other high risk areas.

Our future work with Envision will use detailed decision criteria to select fires based on seasonality and location of ignitions (Figs. 3-5 in Ager et al. 2017) and thus more accurately represent operational practices aimed at increasing the area burned by restoration wildfires. By amplifying specific wildfire events, socioeconomic losses and suppression costs can be minimized while reducing fuels in key areas that can spawn future high severity fires. In a broader context, the agent-based Envision policy modeling system can also be used to investigate many other social and biophysical aspects of wildfires, and contribute to disentangling the potential effects of climate, succession, and management on future fire regimes. Future research with the model can potentially provide insights into the temporal scale mismatches (Cumming et al. 2006) between short- and long-term wildfire risk management that contribute to fragmented wildfire risk governance systems (Steelman 2016).

Responses to this article can be read online at: http://www.ecologyandsociety.org/issues/responses. $\mathrm{php} / 9680$

\section{Acknowledgments:}

This research was funded by the National Science Foundation, Coupled Human and Natural Systems Program (NSF Grant 
CHH-1013296), the USDA Forest Service, Pacific Northwest Research Station, and the Joint Fire Sciences Program grant \# 14-1-01-22 to AA and TS. We are grateful to Bart Johnson and Tim Shehan for their contributions to an earlier version of the wildfire submodel in Envision. We thank Stu Brittain of Alturas Solutions for his development work of the wildfire submodel, and two anonymous reviewers for their comments on an earlier version of the manuscript.

\section{LITERATURE CITED}

Adams, M. A. 2013. Mega-fires, tipping points and ecosystem services: managing forests and woodlands in an uncertain future. Forest Ecology and Management 294:250-261. http://dx.doi. org/10.1016/j.foreco.2012.11.039

Ager, A. A., M. A. Day, C. W. McHugh, K. Short, J. GilbertsonDay, M. A. Finney, and D. E. Calkin. 2014. Wildfire exposure and fuel management on western US national forests. Journal of Environmental Management 145:54-70. http://dx.doi.org/10.1016/ j.jenvman.2014.05.035

Ager, A. A., M. A. Day, K. C. Short, and C. R. Evers. 2016. Assessing the impacts of federal forest planning on wildfire risk mitigation in the Pacific Northwest, USA. Landscape and Urban Planning 147:1-17. http://dx.doi.org/10.1016/j.landurbplan.2015.11.007

Ager, A. A., C. R. Evers, M. A. Day, H. K. Preisler, A. M. G. Barros, and M. Nielsen-Pincus. 2017. Network analysis of wildfire transmission and implications for risk governance. PLoS ONE 12(3):e0172867. http://dx.doi.org/10.1371/journal.pone.0172867

Ager, A. A., M. A. Finney, B. K. Kerns, and H. Maffei. 2007. Modeling wildfire risk to northern spotted owl (Strix occidentalis caurina) habitat in Central Oregon, USA. Forest Ecology and Management 246:45-56. http://dx.doi.org/10.1016/j.foreco.2007.03.070

Ager, A. A., N. M. Vaillant, and M. A. Finney. 2010. A comparison of landscape fuel treatment strategies to mitigate wildland fire risk in the urban interface and preserve old forest structure. Forest Ecology and Management 259(8):1556-1570. http://dx.doi.org/10.1016/j.foreco.2010.01.032

Ager, A. A., N. M. Vaillant, and M. A. Finney. 2011. Integrating fire behavior models and geospatial analysis for wildland fire risk assessment and fuel management planning. Journal of Combustion 572452:19. http://dx.doi.org/10.1155/2011/572452

Andrews, P. L. 2007. BehavePlus fire modeling system: past, present, and future. Pages 1-13 in Proceedings of 7th symposium on fire and forest meteorology. American Meteorological Society, Bar Harbor, Maine, USA. [online] URL: https://www.fs.fed.us/ rm/pubs other/rmrs 2007 andrews p002.pdf

Arkle, R. S., D. S. Pilliod, and J. L. Welty. 2012. Pattern and process of prescribed fires influence effectiveness at reducing wildfire severity in dry coniferous forests. Forest Ecology and Management 276:174-184. http://dx.doi.org/10.1016/j.foreco.2012.04.002

Arno, S. F., and J. K. Brown. 1991. Overcoming the paradox in managing wildland fire. Western Wildlands 17(1):40-46.

Barros, A. M. G., A. A. Ager, M. A. Day, H. K. Preisler, T. A. Spies, E. White, R. Pabst, K. A. Olsen, E. Platt, J. D. Bailey, and J. P. Bolte. 2017. Spatiotemporal dynamics of simulated wildfire, forest management, and forest succession in central Oregon, USA. Ecology and Society 22(1):24. http://dx.doi.org/10.5751/ ES-08917-220124

Boer, M. M., R. J. Sadler, R. S. Wittkuhn, L. McCaw, and P. F. Grierson. 2009. Long-term impacts of prescribed burning on regional extent and incidence of wildfires-evidence from 50 years of active fire management in SW Australian forests. Forest Ecology and Management 259(1):132-142. http://dx.doi. org/10.1016/j.foreco.2009.10.005

Bolte, J. P., D. W. Hulse, S. V. Gregory, and C. Smith. 2004. Modeling biocomplexity - actors, landscapes and alternative futures. Pages 1-10 in C. Pahl-Wostl, S. Schmidt, A. E. Rizzoli, and A. J. Jakeman, editors. Complexity and integrated resources management: transactions of the 2nd biennial meeting of the international environmental modelling and software society. International Environmental Modelling and Software Society, Osnabrück, Germany.

Bradshaw, L. S., J. E. Deeming, R. E. Burgan, and J. D. Cohen. 1984. The 1978 national fire-danger rating system: technical documentation. General Technical Report INT-169. USDA Forest Service, Intermountain Forest and Range Experiment Station, Ogden, Utah, USA. http://www.treesearch.fs.fed.us/ pubs/29615

Brittain, S. 2017. Fire behavior applications and libraries. Alturas Solutions, Missoula, Montana. [online] URL: http://sbrittain. net/fb/fb_api.htm

Brooks, M. L., C. M. D’Antonio, D. M. Richardson, J. B. Grace, J. E. Keeley, J. M. DiTomaso, R. J. Hobbs, M. Pellant, and D. Pyke. 2004. Effects of invasive alien plants on fire regimes. Bioscience 54(7):677-688. https://doi.org/10.1641/0006-3568 (2004)054[0677:EOIAPO]2.0.CO;2

Burscu, T. K., J. S. Halofsky, S. A. Bisrat, T. A. Christopher, M. K. Creutzburg, E. B. Henderson, M. A. Hemstrom, F. J. Triepke, and M. Whitman. 2014. Dynamic vegetation modeling in forest, woodland, shrubland, and grassland vegetation communities in the Pacific Northwest and Southwest regions of the United States. Pages 15-69 in J. E. Halofsky, M. K. Creutzburg, and M. A. Hemstrom, editors. Integrating social, economic, and ecological values across large landscapes. PNW-GTR-896. USDA Forest Service, Pacific Northwest Research Station, Portland, Oregon, USA. [online] URL: https://www.fs.fed.us/pnw/pubs/pnw_gtr896. pdf

Butler, W. H., A. Monroe, and S. McCaffrey. 2015. Collaborative implementation for ecological restoration on US public lands: implications for legal context, accountability, and adaptive management. Environmental Management 55:564-577. http://dx. doi.org/10.1007/s00267-014-0430-8

Calkin, D. E., M. P. Thompson, and M. A. Finney. 2015. Negative consequences of positive feedbacks in US wildfire management. Forest Ecosystems 2(1):1-10. http://dx.doi.org/10.1186/s40663-015-0033-8

Camp, A., C. Oliver, P. Hessburg, and R. Everett. 1997. Predicting late-successional fire refugia pre-dating European settlement in the Wenatchee Mountains. Forest Ecology and Management 95 (1):63-77. http://dx.doi.org/10.1016/S0378-1127(97)00006-6

Charnley, S., T. A. Spies, A. M. G. Barros, E. M. White, and K. A. Olsen. 2017. Diversity in forest management to reduce wildfire 
losses: implications for resilience. Ecology and Society 22(1):22. http://dx.doi.org/10.5751/ES-08753-220122

Cochrane, M. A., C. J. Moran, M. C. Wimberly, A. D. Baer, M. A. Finney, K. L. Beckendorf, J. Eidenshink, and Z. Zhu. 2012. Estimation of wildfire size and risk changes due to fuels treatments. International Journal of Wildland Fire 21(4):357-367. http://dx.doi.org/10.1071/WF11079

Collins, B. M., J. D. Miller, A. E. Thode, M. Kelly, J. W. van Wagtendonk, and S. L. Stephens. 2009. Interactions among wildland fires in a long-established Sierra Nevada natural fire area. Ecosystems 12:114-128. http://dx.doi.org/10.1007/s10021-008-9211-7

Collins, R. D., R. de Neufville, J. Claro, T. Oliveira, and A. P. Pacheco. 2013. Forest fire management to avoid unintended consequences: a case study of Portugal using system dynamics. Journal of Environmental Management 130:1-9. http://dx.doi. org/10.1016/j.jenvman.2013.08.033

Corotis, R. B., and E. M. Hammel. 2010. Multi-attribute aspects for risk assessment of natural hazards. International Journal of Risk Assessment and Management 14(6):437-458. http://dx.doi. org/10.1504/IJRAM.2010.037083

Cumming, G. S., D. H. M. Cumming, and C. L. Redman. 2006. Scale mismatches in social-ecological systems: causes, consequences, and solutions. Ecology and Society 11(1):14. http:// dx.doi.org/10.5751/ES-01569-110114

D'Antonio, C. M., and P. M. Vitousek. 1992. Biological invasions by exotic grasses, the grass/fire cycle, and global change. Annual Review of Ecology and Systematics 23:63-87. https://doi. org/10.1146/annurev.es.23.110192.000431

Davis, R. J., B. Hollen, J. Hobson, J. E. Gower, and D. Keenum. 2016. Northwest forest plan - the first 20 years (1994-2013): status and trends of northern spotted owl habitats. General Technical Report PNW-GTR-929. USDA Forest Service, Pacific Northwest Research Station, Portland, Oregon, USA. [online] URL: https:// www.fs.usda.gov/treesearch/pubs/50567

Dixon, G. E. 2002. Essential FVS: a user's guide to the forest vegetation simulator. Internal report. USDA Forest Service, Forest Management Service Center, Fort Collins, Colorado, USA. [online] URL: http://www.fs.fed.us/fmsc/ftp/fvs/docs/gtr/ EssentialFVS.pdf

Endangered Species Act (ESA). 1973. Endangered species act of 1973, 16 U.S.C.A. section 1531-1544 (1985 and Supp. 2000). [online] URL: http://www.biologicaldiversity.org/campaigns/esa/ esatext.html

Finney, M. A. 2002. Fire growth using minimum travel time methods. Canadian Journal of Forest Research 32(8):1420-1424. http://dx.doi.org/10.1139/x02-068

Finney, M. A. 2006. An overview of FlamMap fire modeling capabilities. Pages 213-220 in P. L. Andrews and B. W. Butler, editors. Fuels management - how to measure success: conference proceedings. Proceedings RMRS-P-41. USDA Forest Service, Rocky Mountain Research Station, Fort Collins, Colorado, USA. [online] URL: https://www.fs.usda.gov/treesearch/pubs/25948

Finney, M. A. 2007. A computational method for optimizing fuel treatment location. International Journal of Wildland Fire 16:702-711. http://dx.doi.org/10.1071/WF06063
Finney, M. A., C. W. McHugh, and I. C. Grenfell. 2005. Standand landscape level effects of prescribed burning on two Arizona wildfires. Canadian Journal of Forest Research 35:1714-1722. http://dx.doi.org/10.1139/x05-090

Finney, M. A., C. W. McHugh, I. C. Grenfell, K. L. Riley, and K. C. Short. 2011. A simulation of probabilistic wildfire risk components for the continental United States. Stochastic Environmental Research and Risk Assessment 25:973-1000. http:// dx.doi.org/10.1007/s00477-011-0462-Z

Finney, M. A., R. C. Seli, C. W. McHugh, A. A. Ager, B. Bahro, and J. K. Agee. 2007. Simulation of long-term landscape-level fuel treatment effects on large wildfires. International Journal of Wildland Fire 16:712-727. http://dx.doi.org/10.1071/WF06064

Fischer, A. P., T. A. Spies, T. A. Steelman, C. Moseley, B. R. Johnson, J. D. Bailey, A. A. Ager, P. Bourgeron, S. Charnley, B. M. Collins, J. D. Kline, J. E. Leahy, J. S. Littell, J. D. A. Millington, M. Nielsen-Pincus, C. S. Olsen, T. B. Paveglio, C. I. Roos, M. M. Steen-Adams, F. R. Stevens, J. Vukomanovic, E. M. White, and D. M. J. S. Bowman. 2016. Wildfire risk as a socioecological pathology. Frontiers in Ecology and the Environment 14 (5):276-284. http://dx.doi.org/10.1002/fee.1283

Fuchs, S., C. Kuhlicke, and V. Meyer. 2011. Editorial for the special issue: vulnerability to natural hazards-the challenge of integration. Natural Hazards 58(2):609-619. http://dx.doi. org/10.1007/s11069-011-9825-5

Guzy, M. R., C. L. Smith, J. P. Bolte, D. W. Hulse, and S. V. Gregory. 2008. Policy research using agent-based modeling to assess future impacts of urban expansion into farmlands and forests. Ecology and Society 13(1):37. http://dx.doi.org/10.5751/ ES-02388-130137

Haire, S. L., K. McGarigal, and C. Miller. 2013. Wilderness shapes contemporary fire size distributions across landscapes of the western United States. Ecosphere 4(1):1-20. http://dx.doi. org/10.1890/ES12-00257.1

Halofsky, J. E., M. K. Creutzburg, and M. A. Hemstrom. 2014. Integrating social, economic, and ecological values across large landscapes. General Technical Report PNW-GTR-896. USDA Forest Service, Pacific Northwest Research Station, Portland, Oregon, USA. http://dx.doi.org/10.2737/PNW-GTR-896

Haugo, R., C. Zanger, T. DeMeo, C. Ringo, A. Shlisky, K. Blankenship, M. Simpson, K. Mellen-McLean, J. Kertis, and M. Stern. 2015. A new approach to evaluate forest structure restoration needs across Oregon and Washington, USA. Forest Ecology and Management 335:37-50. http://dx.doi.org/10.1016/j. foreco.2014.09.014

Hemstrom, M. A., J. Merzenich, A. Reger, and B. Wales. 2007. Integrated analysis of landscape management scenarios using state and transition models in the upper Grande Ronde River Subbasin, Oregon, USA. Landscape and Urban Planning 80 (3):198-211. http://dx.doi.org/10.1016/j.landurbplan.2006.10.004

Hessburg, P. F., T. A. Spies, D. A. Perry, C. N. Skinner, A. H. Taylor, P. M. Brown, S. L. Stephens, A. J. Larson, D. J. Churchill, N. A. Povak, P. H. Singleton, B. McComb, W. J. Zielinski, B. M. Collins, R. B. Salter, J. J. Keane, J. F. Franklin, and G. Riegel. 2016. Tamm review: management of mixed-severity fire regime forests in Oregon, Washington, and Northern California. Forest 
Ecology and Management 366:221-250. http://dx.doi.org/10.1016/ j.foreco.2016.01.034

Hill, B. T. 2000. Fire management: lessons learned from the Cerro Grande (Los Alamos) fire. Statement to the Committee on Energy and Natural Resources, U.S. Senate GAO/T-RCED-00-257. United States General Accounting Office, Washington, D.C., USA. [online] URL: http://www.gao.gov/products/GAO/T$\underline{\text { RCED-00-257 }}$

Hmielowski, T. L., S. K. Carter, H. Spaul, D. Helmers, V. C. Radeloff, and P. Zedler. 2016. Prioritizing land management efforts at a landscape scale: a case study using prescribed fire in Wisconsin. Ecological Applications 26(4):1018-1029. http://dx. doi.org/10.1890/15-0509

Hoff, V., C. C. Teske, J. P. Riddering, L. P. Queen, E. G. Gdula, and W. A. Bunn. 2014. Changes in severity distribution after subsequent fires on the North Rim of Grand Canyon National Park, Arizona, USA. Fire Ecology 10(2):48-63. http://dx.doi. org/10.4996/fireecology.1002048

Holsinger, L., S. A. Parks, and C. Miller. 2016. Weather, fuels, and topography impede wildland fire spread in western US landscapes. Forest and Ecology Management 380:59-69. http://dx. doi.org/10.1016/j.foreco.2016.08.035

Houtman, R. M., C. A. Montgomery, A. R. Gagnon, D. E. Calkin, T. G. Dietterich, S. McGregor, and M. Crowley. 2013. Allowing a wildfire to burn: estimating the effect on future fire suppression costs. International Journal of Wildland Fire 22 (7):871-882. http://dx.doi.org/10.1071/WF12157

Hulse, D., A. Branscomb, C. Enright, and J. Bolte. 2009. Anticipating floodplain trajectories: a comparison of two alternative futures approaches. Landscape Ecology 24:1067-1090. http://dx.doi.org/10.1007/s10980-008-9255-2

Hulse, D., C. Branscomb, C. Enright, B. Johnson, C. Evers, J. Bolte, and A. Ager. 2016. Anticipating surprise: using agent-based alternative futures simulation modeling to identify and map surprising fires in the Willamette Valley, Oregon USA. Landscape and Urban Planning 156:26-43. http://dx.doi.org/10.1016/j. landurbplan.2016.05.012

Jakes, P., S. Burns, A. Cheng, E. Saeli, K. Nelson, R. Brummel, S. Grayzeck, V. Sturtevant, and D. Williams. 2007. Critical elements in the development and implementation of community wildfire protection plans (CWPPs). Pages 613-625 in B. W. Butler and W. Cook, editors. The fire environment - innovations, management and policy: conference proceedings. Proc. RMRSP-46CD. USDA Forest Service, Rocky Mountain Research Station, Fort Collins, Colorado, USA. [online] URL: https:// www.fs.usda.gov/treesearch/pubs/28604

Kalabokidis, K., N. Athanasis, C. Vasilakos, and P. Palaiologou. 2014. Porting of a wildfire risk and fire spread application into a cloud computing environment. International Journal of Geographical Information Science 28(3):541-552. http://dx.doi. org/10.1080/13658816.2013.858257

Kalies, E. L., and L. L. Yocom Kent. 2016. Tamm review: are fuel treatments effective at achieving ecological and social objectives? A systematic review. Forest Ecology and Management 375:84-95. http://dx.doi.org/10.1016/j.foreco.2016.05.021
Kerns, B. K., and A. Ager. 2007. Risk assessment for biodiversity conservation planning in Pacific Northwest Forests. Forest Ecology and Management 246:38-44. http://dx.doi.org/10.1016/j. foreco.2007.03.049

Kim, Y.-H., P. Bettinger, and M. Finney. 2009. Spatial optimization of the pattern of fuel management activities and subsequent effects on simulated wildfires. European Journal of Operational Research 197:253-265. http://dx.doi.org/10.1016/j. ejor.2008.05.025

Kline, J. D., E. M. White, A. P. Fischer, M. M. Steen-Adams, S. Charnley, C. S. Olsen, T. A. Spies, and J. D. Bailey. 2017. Integrating social science into empirical models of coupled human and natural systems. Ecology and Society 22(3):25. http:// dx.doi.org/10.5751/ES-09329-220325

Konoshima, M., C. A. Montgomery, H. J. Albers, and J. L. Arthur. 2008. Spatial-endogenous fire risk and efficient fuel management and timber harvest. Land Economics 84:449-468. http://dx.doi. org/10.3368/le.84.3.449

LANDFIRE. 2013. 40 Scott and Burgan fire behavior fuel models (FBFM40). Department of Interior, U.S. Geological Survey, Reston, Virginia, USA. [online] URL: http://www.landfire.gov/ NationalProductDescriptions2.php

Lehmkuhl, J. F., M. Kennedy, E. D. Ford, P. H. Singleton, W. L. Gaines, and R. L. Lind. 2007. Seeing the forest for the fuel: integrating ecological values and fuels management. Forest Ecology and Management 246:73-80. http://dx.doi.org/10.1016/j. foreco.2007.03.071

Liu, J. C., G. Pereira, S. A. Uhl, M. A. Bravo, and M. L. Bell. 2015. A systematic review of the physical health impacts from non-occupational exposure to wildfire smoke. Environmental Research 136:120-132. http://dx.doi.org/10.1016/j.envres.2014.10.015

Loehle, C. 1999. Optimizing wildlife habitat mitigation with a habitat defragmentation algorithm. Forest Ecology and Management 120:245-251. http://dx.doi.org/10.1016/S0378-1127 (98)00546-5

Loudermilk, E. L., A. Stanton, R. M. Scheller, T. E. Dilts, P. J. Weisberg, C. Skinner, and J. Yang. 2014. Effectiveness of fuel treatments for mitigating wildfire risk and sequestering forest carbon: a case study in the Lake Tahoe Basin. Forest Ecology and Management 323:114-125. http://dx.doi.org/10.1016/j.foreco.2014.03.011

McKenzie, D., Z. e. Gedalof, D. L. Peterson, and P. Mote. 2004. Climatic change, wildfire, and conservation. Conservation Biology 18(4):890-902. http://dx.doi.org/10.1111/j.1523-1739.2004.00492. $\underline{\mathrm{X}}$

McKenzie, D., and J. S. Littell. 2017. Climate change and the ecohydrology of fire: will area burned increase in a warming western USA? Ecological Applications 27(1):26-36. http://dx.doi. org/10.1002/eap.1420

Merschel, A. G., T. A. Spies, and E. K. Heyerdahl. 2014. Mixedconifer forests of central Oregon: effects of logging and fire exclusion vary with environment. Ecological Applications 24 (7):1670-1688. http://dx.doi.org/10.1890/13-1585.1

Moghaddas, J. J., B. M. Collins, K. Menning, E. E. Y. Moghaddas, and S. L. Stephens. 2010. Fuel treatment effects on modeled 
landscape-level fire behavior in the northern Sierra Nevada Canadian Journal of Forest Research 40:1751-1765. http://dx.doi. org/10.1139/X10-118

Moghaddas, J. J., and L. Craggs. 2007. A fuel treatment reduces fire severity and increases suppression efficiency in a mixed conifer forest. International Journal of Wildland Fire 16(6):673-678. http://dx.doi.org/10.1071/WF06066

National Wildfire Coordinating Group (NWCG). 2013. Wildland fire incident management field guide. PMS 210. National Wildfire Coordinating Group, Boise, Idaho, USA. [online] URL: https:// www.nwcg.gov/sites/default/files/publications/pms210.pdf

Noonan-Wright, E. K., T. S. Opperman, M. A. Finney, G. T. Zimmerman, R. C. Seli, L. M. Elenz, D. E. Calkin, and J. R. Fiedler. 2011. Developing the US wildland fire decision support system. Journal of Combustion 2011:168473. http://dx.doi. org/10.1155/2011/168473

North, M., A. Brough, J. Long, B. Collins, P. Bowden, D. Yasuda, J. Miller, and N. Sugihara. 2015. Constraints on mechanized treatment significantly limit mechanical fuels reduction extent in the Sierra Nevada. Journal of Forestry 113(1):40-48. http://dx.doi. org/10.5849/jof.14-058

North, M., B. M. Collins, and S. Stephens. 2012. Using fire to increase the scale, benefits, and future maintenance of fuels treatments. Journal of Forestry 110(7):392-401. http://dx.doi. org/10.5849/jof.12-021

Noss, R. F., J. F. Franklin, W. L. Baker, T. Schoennagel, and P. B. Moyle. 2006. Managing fire-prone forests in the western United States. Frontiers in Ecology and the Environment 4:481-487. http:// dx.doi.org/10.1890/1540-9295(2006)4[481:MFFITW]2.0.CO;2

Oliveira, T. M., A. M. G. Barros, A. A. Ager, and P. M. Fernandes. 2016. Assessing the effect of a fuel break network to reduce burnt area and wildfire risk transmission. International Journal of Wildland Fire 25(6):619-632. http://dx.doi.org/10.1071/WF15146

Parisien, M.-A., D. R. Junor, and V. G. Kafka. 2007. Comparing landscape-based decision rules of placement of fuel treatments in the boreal mixedwood of western Canada. International Journal of Wildland Fire 16:664-672. http://dx.doi.org/10.1071/ WF06060

Parks, S. A., L. M. Holsinger, C. Miller, and C. R. Nelson. $2015 b$. Wildland fire as a self-regulating mechanism: the role of previous burns and weather in limiting fire progression. Ecological Applications 25(6):1478-1492. http://dx.doi.org/10.1890/14-1430.1

Parks, S. A., C. Miller, L. M. Holsinger, L. S. Baggett, and B. J. Bird. 2015c. Wildland fire limits subsequent fire occurrence. International Journal of Wildland Fire 25(2):182-190. http://dx. doi.org/10.1071/WF15107

Parks, S. A., C. Miller, C. R. Nelson, and Z. A. Holden. 2014. Previous fires moderate burn severity of subsequent wildland fires in two large western US wilderness areas. Ecosystems 17(1):29-42. http://dx.doi.org/10.1007/s10021-013-9704-x

Parks, S. A., C. Miller, M.-A. Parisien, L. M. Holsinger, S. Z. Dobrowski, and J. Abatzoglou. 2015a. Wildland fire deficit and surplus in the western United States, 1984-2012. Ecosphere 6 (12):1-13. http://dx.doi.org/10.1890/ES15-00294.1
Platt, E. K. 2014. Managing for landscape resilience in the frequentfire forests of central Oregon. Dissertation. Oregon State University, Corvallis, Oregon, USA. [online] URL: https://ir. library.oregonstate.edu/xmlui/bitstream/handle/1957/51761/ PlattEmilyK2014.pdf?sequence $=1$

Preisler, H. K., and A. A. Ager. 2013. Forest-fire models. Pages 1081-1088 in A. H. El-Shaarawi and W. Piegorsch, editors. Encyclopedia of environmetrics. John Wiley and Sons, Chichester, UK.

Preisler, H. K., D. R. Brillinger, R. E. Burgan, and J. W. Benoit. 2004. Probability based models for estimating wildfire risk. International Journal of Wildland Fire 13:133-142. http://dx.doi. org/10.1071/WF02061

Prestemon, J. P., U. Shankar, A. Xiu, K. Talgo, D. Yang, E. Dixon, IV, D. McKenzie, and K. L. Abt. 2016. Projecting wildfire area burned in the south-eastern United States, 2011-60. International Journal of Wildland Fire 25(7):715-729. http://dx.doi.org/10.1071/ $\underline{\mathrm{WF} 15124}$

Price, O. E., R. A. Bradstock, J. E. Keeley, and A. D. Syphard. 2012. The impact of antecedent fire area on burned area in southern California coastal ecosystems. Journal of Environmental Management 113:301-307. http://dx.doi.org/10.1016/j. jenvman.2012.08.042

Price, O. F., J. G. Pausas, N. Govender, M. Flannigan, P. M. Fernandes, M. L. Brooks, and R. B. Bird. 2015. Global patterns in fire leverage: the response of annual area burnt to previous fire. International Journal of Wildland Fire 24(3):297-306. http://dx. doi.org/10.1071/WF14034

Prichard, S. J., and M. C. Kennedy. 2014. Fuel treatments and landform modify landscape patterns of burn severity in an extreme fire event. Ecological Applications 24(3):571-590. http:// dx.doi.org/10.1890/13-0343.1

Prichard, S. J., D. L. Peterson, and K. Jacobson. 2010. Fuel treatments reduce the severity of wildfire effects in dry mixed conifer forest, Washington, USA. Canadian Journal of Forest Research 40:1615-1626. http://dx.doi.org/10.1139/X10-109

Prichard, S. J., C. S. Stevens-Rumann, and P. F. Hessburg. 2017. Tamm review: shifting global fire regimes: lessons from reburns and research needs. Forest Ecology and Management 396:217-233. http://dx.doi.org/10.1016/j.foreco.2017.03.035

R Core Team. 2014. R: A language and environment for statistical computing. Version 3.1.1. R Foundation for Statistical Computing, Vienna, Austria. [online] URL: http://www.Rproject.org/

Reinhardt, E. D., and N. L. Crookston. 2003. The fire and fuels extension to the Forest Vegetation Simulator. General Technical Report. RMRS-GTR-116, USDA Forest Service, Rocky Mountain Research Station, Ogden, Utah, USA. http://dx.doi. org/10.2737/RMRS-GTR-116

Ryan, K. C., E. E. Knapp, and J. M. Varner. 2013. Prescribed fire in North American forests and woodlands: history, current practice, and challenges. Frontiers in Ecology and the Environment 11(s1):e15-e24. http://dx.doi.org/10.1890/120329

Safford, H. D., D. A. Schmidt, and C. H. Carlson. 2009. Effects of fuel treatments on fire severity in an area of wildland-urban 
interface, Angora Fire, Lake Tahoe Basin, California. Forest Ecology and Management 258:773-787. http://dx.doi.org/10.1016/ j.foreco.2009.05.024

Salis, M., A. A. Ager, F. J. Alcasena, B. Arca, M. A. Finney, G. Pellizzaro, and D. Spano. 2015. Analyzing seasonal patterns of wildfire exposure factors in Sardinia, Italy. Environmental Monitoring and Assessment 187(1):1-20. http://dx.doi.org/10.1007/ $\underline{\text { s10661-014-4175-X }}$

Scheller, R. M., and D. J. Mladenoff. 2007. An ecological classification of forest landscape simulation models: tools and strategies for understanding broad-scale forested ecosystems. Landscape Ecology 22(4):491-505. http://dx.doi.org/10.1007/ s10980-006-9048-4

Schweizer, D. W., and R. Cisneros. 2017. Forest fire policy: change conventional thinking of smoke management to prioritize longterm air quality and public health. Air Quality, Atmosphere and Health 10(1):33-36. http://dx.doi.org/10.1007/s11869-016-0405-4

Scott, J. H., and R. E. Burgan. 2005. Standard fire behavior fuel models: a comprehensive set for use with Rothermel's surface fire spread model. General Technical Report RMRS-GTR-153. USDA Forest Service, Rocky Mountain Research Station, Fort Collins, Colorado, USA. http://dx.doi.org/10.2737/RMRS$\underline{\text { GTR-153 }}$

Short, K. C. 2014. A spatial database of wildfire in the United States, 1992-2011. Earth System Science Data 6:1-27. http://dx. doi.org/10.5194/essd-6-1-2014

Spies, T. A., E. White, A. Ager, J. D. Kline, J. P. Bolte, E. K. Platt, K. A. Olsen, R. J. Pabst, A. M. G. Barros, J. D. Bailey, S. Charnley, J. Koch, M. M. Steen-Adams, P. H. Singleton, J. Sulzman, C. Schwartz, and B. Csuiti. 2017. Using an agent-based model to examine forest management outcomes in a fire-prone landscape in Oregon, USA. Ecology and Society 22(1):25. http://dx.doi. org/10.5751/ES-08841-220125

Spies, T. A., E. M. White, J. D. Kline, A. P. Fischer, A. Ager, J. Bailey, J. Bolte, J. Koch, E. Platt, C. S. Olsen, D. Jacobs, B. Shindler, M. M. Steen-Adams, and R. Hammer. 2014. Examining fire-prone forest landscapes as coupled human and natural systems. Ecology and Society 19(3):9. http://dx.doi.org/10.5751/ ES-06584-190309

Steelman, T. 2016. U.S. wildfire governance as a social-ecological problem. Ecology and Society 21(4):3. http://dx.doi.org/10.5751/ ES-08681-210403

Stephens, S. L., J. D. McIver, R. E. J. Boerner, C. J. Fettig, J. B. Fontaine, B. R. Hartsough, P. L. Kennedy, and D. W. Schwilk. 2012. The effects of forest-reduction treatments in the United States. Bioscience 62(6):549-560. http://dx.doi.org/10.1525/ bio.2012.62.6.6

Syphard, A. D., J. E. Keeley, and T. J. Brennan. 2011b. Factors affecting fuel break effectiveness in the control of large fires on the Los Padres National Forest, California. International Journal of Wildland Fire 20:764-775. http://dx.doi.org/10.1071/WF10065

Syphard, A. D., R. M. Scheller, B. C. Ward, W. D. Spencer, and J. R. Strittholt. 2011a. Simulating landscape-scale effects of fuels treatments in the Sierra Nevada, California, USA. International Journal of Wildland Fire 20(3):364-383. http://dx.doi.org/10.1071/ $\underline{\mathrm{WF} 09125}$

Teske, C. C., C. A. Seielstad, and L. P. Queen. 2012. Characterizing fire-on-fire interactions in three large wilderness areas. Fire Ecology 8(2):82-106. http://dx.doi.org/10.4996/ fireecology.0802082

Thompson, M. P., P. Freeborn, J. D. Rieck, D. E. Calkin, J. W. Gilbertson-Day, M. A. Cochrane, and M. S. Hand. 2016. Quantifying the influence of previously burned areas on suppression effectiveness and avoided exposure: a case study of the Las Conchas Fire. International Journal of Wildland Fire 25 (2):167-181. http://dx.doi.org/10.1071/WF14216

United States Department of Agriculture/United States Department of Interior (USDA/USDI). 2009. Guidance for implementation of federal wildland fire management policy. US Department of Agriculture and US Department of Interior, Washington, D.C., USA. [online] URL: https://www.nifc.gov/ policies/policies documents/GIFWFMP.pdf

United States Department of Agriculture/United States Department of Interior (USDA/USDI). 2014. The national strategy: the final phase in the development of the national cohesive wildland fire management strategy. US Department of Agriculture and US Department of Interior, Washington, D.C., USA. [online] URL: http://www.forestsandrangelands.gov/index.shtml

United States Department of Agriculture Forest Service (USDA FS). 1990. Deschutes national forest: land and resource management plan. USDA Forest Service, Pacific Northwest Region, Portland, Oregon, USA. [online] URL: http://www.fs. usda.gov/detail/deschutes/landmanagement/planning/?cid= fsbdev3 035906

United States Department of Agriculture Forest Service (USDA FS). 2012. Increasing the pace of restoration and job creation on our national forests. USFS Report. United States Department of Agriculture, Forest Service, Washington, D.C., USA. [online] URL: http://www.fs.fed.us/sites/default/files/media/types/publication/ field_pdf/increasing-pace-restoration-job-creation-2012.pdf

United States Department of Agriculture Forest Service (USDA FS). 2015a. From accelerating restoration to creating and maintaining resilient landscapes and communities across the nation: update on progress from 2012. FS-1069. United States Department of Agriculture, Forest Service, Washington, D.C., USA. [online] URL: http://www.fs.fed.us/sites/default/files/accelerating-restorationupdate-2015-508-compliant.pdf

United States Department of Agriculture Forest Service (USDA FS). 2015b. The rising cost of wildfire operations: effects on the Forest Service's non-fire work. United States Department of Agriculture, Forest Service, Washington, D.C., USA. [online] URL: https://www.fs.fed.us/sites/default/files/2015-Rising-CostWildfire-Operations.pdf

United States Department of Agriculture Office of Inspector General(USDA OIG). 2016. Forest Service wildland fire activities - hazardous fuels reduction. Audit report 08601-0001-41. USDA Office of Inspector General, Washington, D.C., USA. [online] URL: https://www.usda.gov/oig/webdocs/08601-0004-41.pdf 
Wei, Y., D. Rideout, and A. Kirsch. 2008. An optimization model for locating fuel treatments across a landscape to reduce expected fire losses. Canadian Journal of Forest Research 38(4):868-877. http://dx.doi.org/10.1139/X07-162

Western Regional Climate Center (WRCC). 2014. RAWS USA climate archive. Western Regional Climate Center, Reno, Nevada, USA. [online] URL: http://www.raws.dri.edu/

Wonkka, C. L., W. E. Rogers, and U. P. Kreuter. 2015. Legal barriers to effective ecosystem management: exploring linkages between liability, regulations, and prescribed fire. Ecological Applications 25(8):2382-2393. http://dx.doi.org/10.1890/14-1791.1

Wood, S. N. 2006. Generalized additive models: an introduction with R. Chapman and Hall/CRC, Boca Raton, Florida, USA.

Wood, S. N. 2011. Fast stable restricted maximum likelihood and marginal likelihood estimation of semiparametric generalized linear models. Journal of the Royal Statistical Society: Series B (Statistical Methodology) 73(1):3-36. http://dx.doi.org/10.1111/ j.1467-9868.2010.00749.x 


\section{Appendix 1. Vegetation Succession.}

Table A1.1. Potential vegetation type (PVT) descriptions and management group by each of the Vegetation Dynamics Development Tool (VDDT) modeling regions in the study area.

\begin{tabular}{|c|c|c|}
\hline VDDT modeling region & PVT description & PVT management group \\
\hline Oregon Blue Mountains & Grand fir - cool, moist & Moist mixed conifer \\
\hline Oregon Blue Mountains & Subalpine fir - cold, dry & Moist, high elevation, other \\
\hline Oregon Blue Mountains & Subalpine woodland & Moist, high elevation, other \\
\hline Oregon Blue Mountains & Ponderosa pine - dry, with juniper & Ponderosa pine \\
\hline Oregon Blue Mountains & Ponderosa pine - xeric & Ponderosa pine \\
\hline Oregon Blue Mountains & Mountain hemlock - cold, dry & Moist, high elevation, other \\
\hline Oregon Blue Mountains & Mixed conifer - cold, dry & Dry mixed conifer \\
\hline Southeast Oregon & Mixed conifer - cold, dry & Dry mixed conifer \\
\hline Southeast Oregon & Mixed conifer - dry (pumice soils) & Dry mixed conifer \\
\hline Southeast Oregon & Ponderosa pine - dry (residual soils) & Ponderosa pine \\
\hline Southeast Oregon & Ponderosa pine - xeric & Ponderosa pine \\
\hline Oregon East Cascades & Western hemlock - wet & Moist, high elevation, other \\
\hline Oregon East Cascades & Western hemlock - intermediate & Moist, high elevation, other \\
\hline Oregon East Cascades & Western hemlock - cold & Moist, high elevation, other \\
\hline Oregon East Cascades & Pacific silver fir - warm & Moist, high elevation, other \\
\hline Oregon East Cascades & Pacific silver fir - intermediate & Moist, high elevation, other \\
\hline Oregon East Cascades & Mountain hemlock - intermediate & Moist, high elevation, other \\
\hline Oregon East Cascades & Mixed conifer - moist & Moist mixed conifer \\
\hline Oregon East Cascades & Oregon white oak / Ponderosa pine & Ponderosa pine \\
\hline Oregon East Cascades & Subalpine parkland & Moist, high elevation, other \\
\hline Oregon East Cascades & Shasta red fir - dry & Moist, high elevation, other \\
\hline Oregon East Cascades & Mixed conifer - dry (pumice soils) & Dry mixed conifer \\
\hline Oregon East Cascades & Lodgepole pine - wet & Lodgepole \\
\hline Oregon East Cascades & Lodgepole pine - dry & Lodgepole \\
\hline Oregon East Cascades & Ponderosa pine - dry (residual soils) & Ponderosa pine \\
\hline Oregon East Cascades & Mixed conifer - dry & Dry mixed conifer \\
\hline Oregon East Cascades & Mixed conifer - cold, dry & Dry mixed conifer \\
\hline Oregon East Cascades & Mountain hemlock & Moist, high elevation, other \\
\hline Oregon East Cascades & Ponderosa pine - xeric & Ponderosa pine \\
\hline Oregon East Cascades & Ponderosa pine - Lodgepole pine & Dry mixed conifer \\
\hline
\end{tabular}


Table A1.1. Contd.

\begin{tabular}{lll}
\hline \hline VDDT modeling region & PVT description & PVT management group \\
\hline Southwest Oregon & Subalpine parkland & Moist, high elevation, other \\
Southwest Oregon & Mountain hemlock - cold, dry & Moist, high elevation, other \\
Southwest Oregon & Shasta red fir - moist & Moist, high elevation, other \\
Southwest Oregon & White fir - cool & Moist mixed conifer \\
Southwest Oregon & White fir - intermediate & Dry mixed conifer \\
Southwest Oregon & Douglas-fir - moist & Dry mixed conifer \\
Southwest Oregon & Douglas-fir - dry & Dry mixed conifer \\
Southwest Oregon & Oregon white oak & Moist, high elevation, other \\
Southwest Oregon & Ponderosa pine - dry, with juniper & Ponderosa pine \\
\hline
\end{tabular}

Table A1.2. Structural stage attributes assigned to each of 39 potential vegetation types (PVT, Table A1.1) to define 565 unique vegclasses, thus each vegclass includes a combination of PVT, tree size, canopy cover and layering.

\begin{tabular}{ll}
\hline \hline Structural stage attribute & Class \\
\hline Size $(\mathrm{dbh})$ & Barren \\
& Meadow \\
& Shrubs \\
& Seedling/sapling \\
& Pole $(0.13-0.25 \mathrm{~m})$ \\
& Small tree $(0.25-0.38 \mathrm{~m})$ \\
& Medium tree $(0.38-0.51 \mathrm{~m})$ \\
& Large tree $(0.51-0.76 \mathrm{~m})$ \\
& Giant tree $(>0.76 \mathrm{~m})$ \\
\hline Canopy cover & Low (open, 10-40\%) \\
& Medium $(40-60 \%)$ \\
& High (closed, $>60 \%)$ \\
& Post-disturbance \\
\hline Layering & None \\
& Single \\
& Multi \\
\hline
\end{tabular}




\section{Appendix 2. Management, Wildfire and Fuels.}

Table A2.1. Effect of fire severity and management action on tree size, canopy cover, canopy layering and surface fuels.

\begin{tabular}{ll}
\hline \hline Fire severity/management activity & Effect of disturbance \\
\hline Surface fire (includes prescribed fire) & $\begin{array}{l}\text { Reduces surface fuels; reduces multi-layer states to a } \\
\text { single layer for some vegetation states }\end{array}$ \\
Mixed-severity fire & $\begin{array}{l}\text { Reduces surface fuels; reduces multi-layer states to a } \\
\text { single layer; decreases canopy cover by one or two } \\
\text { classes }\end{array}$ \\
& $\begin{array}{l}\text { Reduces surface fuels and no canopy layers remain; } \\
\text { decreases canopy cover to none or low; trees are killed }\end{array}$ \\
Stand-replacing fire & with transition to grass-forb or shrub vegetation states \\
& Eliminates shrub layers and increases surface fuels \\
& Increases surface fuels; decreases high canopy cover to \\
Mowing and grinding & moderate or low cover \\
Pre-commercial thinning & Increases surface fuels; generally reduces multi-layer \\
& states to single layer; decreases high canopy cover to \\
Thin from below & moderate \\
& Increases surface fuels; generally reduces multi-layer \\
states to single layer; generally decreases canopy cover \\
byrtial harvest
\end{tabular}




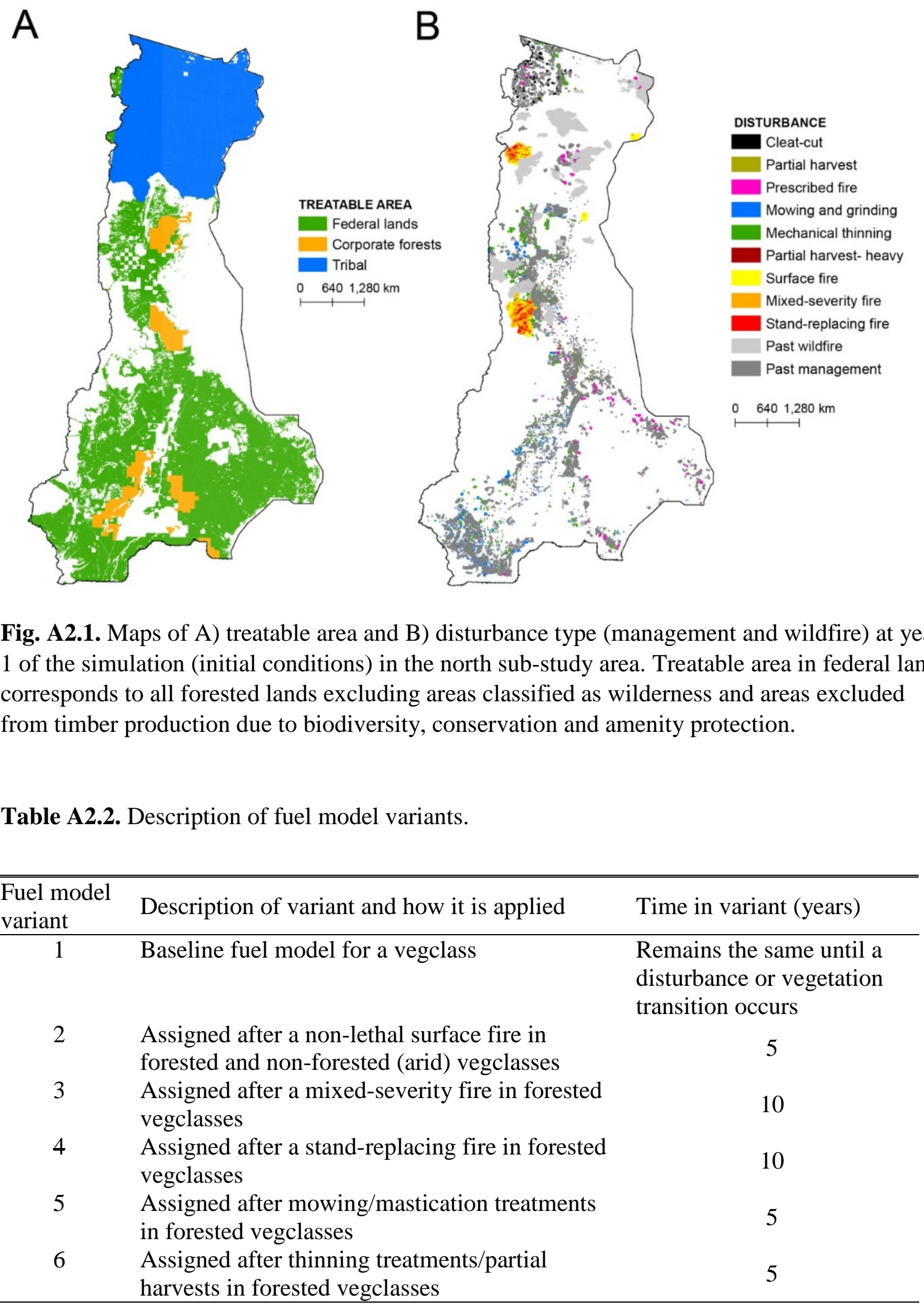


Table A2.3. Fuel model codes assigned to post-disturbance conditions. All models are described in Scott and Burgan (2005) with exception of MAST, a custom fuel model for masticated fuel beds.

\begin{tabular}{cccccc}
\hline Baseline & $\begin{array}{c}\text { Surface fire } \\
\text { or prescribed } \\
\text { fire }\end{array}$ & $\begin{array}{c}\text { Mixed } \\
\text { severity fire }\end{array}$ & $\begin{array}{c}\text { Stand- } \\
\text { replacing fire }\end{array}$ & Mastication & Thinning \\
\hline $\begin{array}{c}\text { Until } \\
\text { transition/ }\end{array}$ & 10 years & 10 years & 10 years & 5 years & 5 years \\
disturbance & & & & & \\
NB3 & NB3 & NB3 & NB3 & NB3 & NB3 \\
NB8 & NB8 & NB8 & NB8 & NB8 & NB8 \\
GR1 & TL1 & GR1 & TL1 & GR1 & GR1 \\
GR2 & TL2 & GR2 & TL1 & GR2 & GR2 \\
GR3 & TL2 & GR2 & TL1 & GR2 & GR3 \\
GS1 & TL2 & GS1 & TL1 & MAST & TL5 \\
GS2 & TL2 & GR2 & TL1 & MAST & TL5 \\
SH1 & TL2 & GS1 & TL1 & MAST & TL5 \\
SH2 & TL2 & GS2 & TL1 & MAST & TL5 \\
TU1 & TL2 & GR2 & TL1 & MAST & TL5 \\
TU4 & TL1 & TL1 & TL1 & MAST & TL5 \\
TU5 & TL1 & TL1 & TL1 & MAST & TL5 \\
TL1 & TL1 & TL1 & TL1 & MAST & TL5 \\
TL2 & TL1 & TL1 & TL1 & MAST & TL5 \\
TL3 & TL1 & TL1 & TL1 & MAST & TL5 \\
TL4 & TL1 & TL1 & TL1 & MAST & TL5 \\
TL5 & TL1 & TL1 & TL1 & MAST & TL5 \\
TL6 & TL1 & TL1 & TL1 & MAST & TL5 \\
TL7 & TL1 & TL1 & TL1 & MAST & TL5 \\
TL8 & TL1 & TL1 & TL1 & MAST & TL5 \\
TL9 & TL1 & TL1 & TL1 & MAST & TL5 \\
\hline
\end{tabular}

\section{LITERATURE CITED}

Scott, J. H. and R. E. Burgan. 2005. Standard fire behavior fuel models: a comprehensive set for use with Rothermel's surface fire spread model. Gen. Tech. Rep. RMRS-GTR-153, USDA Forest Service, Rocky Mountain Research Station. 
Appendix 3. Additional Fire Perimeter Analysis.

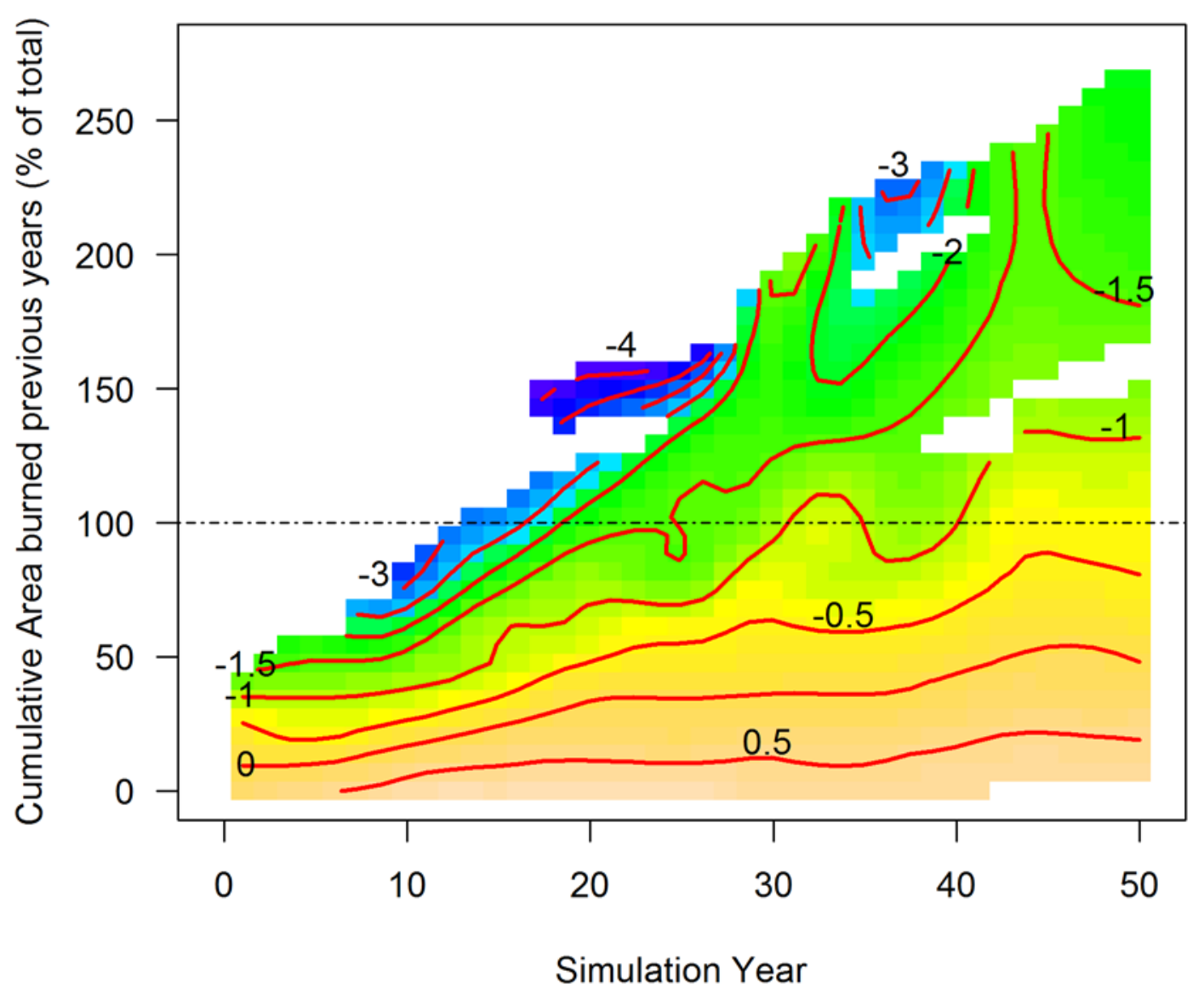

Fig. A3.1. Contour plot of change in average rate of spread $\left(\mathrm{m} \mathrm{min}^{-1}\right)$ relative to the mean rate of spread as a function of simulation year and percentage of study area previously burned. The dashed line indicates the level at which an area equivalent to the whole study area $(100 \%)$ was burned in previous years. Contour $=0$ represents no change relative to average rate of spread. 


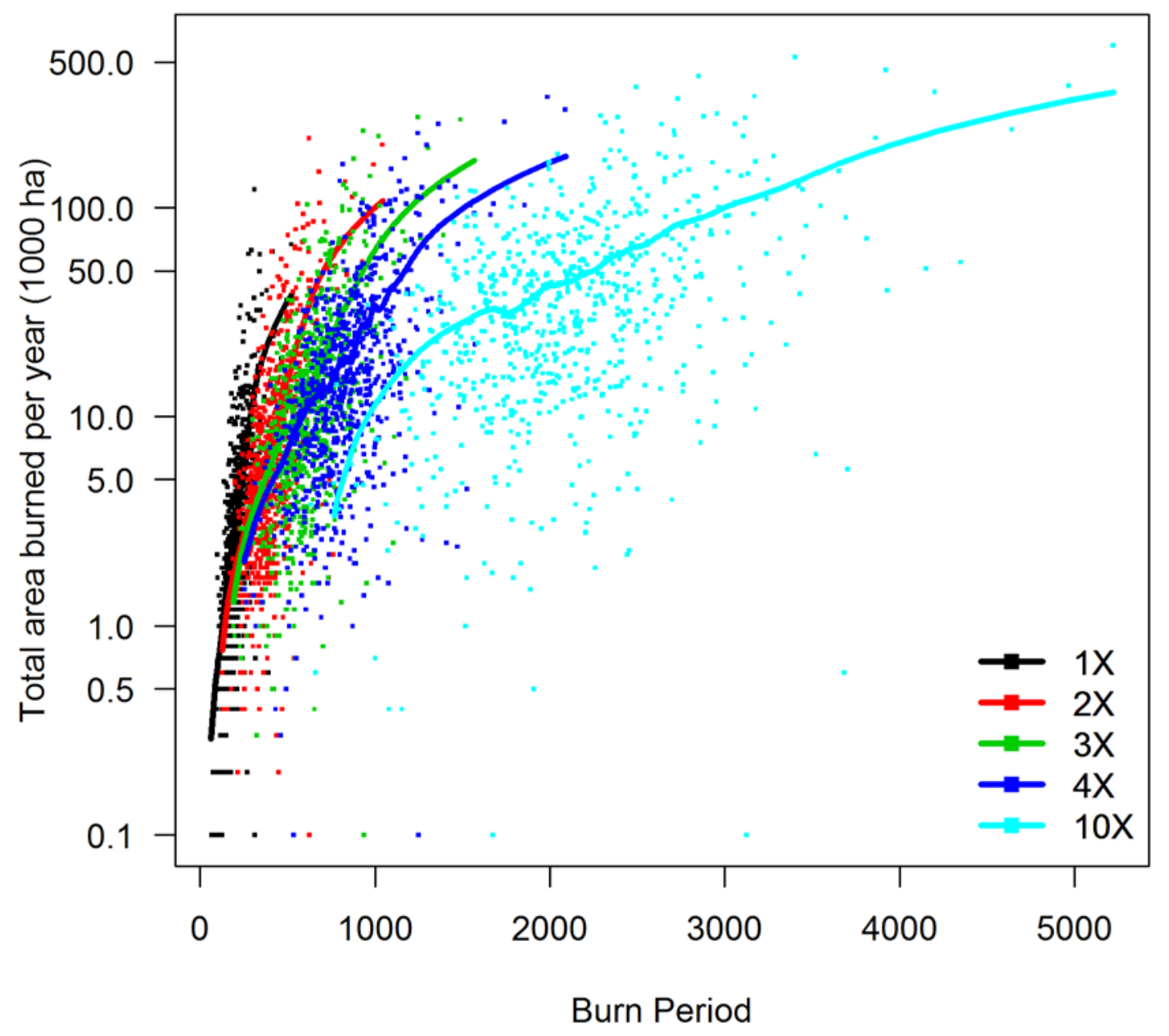

Fig. A3.2. Total area burned (1000 ha) as a function of burn period (minutes) for wildfire scenario (1X, 2X, 3X, 4X and 10X). Increased levels of wildfire activity in each scenario were achieved by multiplying the burn period of each ignition over contemporary levels by the multiplier indicated. 